\title{
SAN FRANCISCO BAY: REGIONAL REGULATION FOR ITS PROTECTION AND DEVELOPMENT
}

San Francisco Bay has been disappearing at the rate of three and one-half square miles a year. ${ }^{1}$ Over the last hundred years, filling and diking have removed over 240 square miles from the Bay. At the present rate, it will take less than one hundred years to deprive the Bay of the 326 miles still susceptible of reclamation. ${ }^{2}$ This Comment will describe the undesirable effects of Bay fill and analyze the legal aspects of its regional control.

Part I describes both the complex natural functions served by the Bay and the commercial interests which shrink the Bay by fill and development. The Bay supports an intricate and delicate array of natural life, serves as a major recreational site, significantly affects the climate of the region, and provides the aesthetic theme for the entire region. These functions are undermined when commercial interests fill and develop the Bay to satisfy urban pressure for more space. ${ }^{3}$ Clearly, the Bay must be preserved, but, just as clearly, preservation cannot mean an unbending worship of the status quo. As a region changes, the role of its natural resources must change with it. Therefore, a central problem facing all regions with a natural asset like the Bay is to decide which changes are consistent with the needs of the region.

To resolve this problem the California Legislature has established the San Francisco Bay Conservation and Development Commission (BCDC). ${ }^{4}$ This Commission is presently empowered to approve or deny requests to fill or dredge the Bay" and to formulate "a comprehensive and enforceable plan for the conservation of the water of San Francisco Bay and the development of its shoreline." ${ }^{6}$ The BCDC can implement this future plan in several ways. One is to use the power of eminent domain. Since Berman v. Parker $^{7}$ there can be no doubt that $\mathrm{BCDC}$ could control development

1 U.S. Dep't of Comanerce, Future Developarent of the San Francisco Bay AREs 1960-2020, at 80 (1959). This statistic does not reflect the reduction in filling since 1965 due to the San Francisco Bay Conservation and Development Commission (BCDC).

2 See id. at $78-80$.

3 Filling is commorcially feasible because one-half of the Bay is six feet deep or less. G. Delisle, Preliminary Fish and Wildlife Plan for San Francisco Bay-Estuary, Oct. 1966, at 24 (BCDC).

${ }^{4}$ CaL. Gov't CoDE $\S \S 66600-53$ (West 1966). The Commission's responsibilities terminate' on the 90th day after the final adjournment of the legislature's 1969 Regular Session. Id. $\S 66652$. The discussion in this Comment assumes that the legislature will reenact the Commission in permanent form.

$5 I d . \S 66632$.

${ }^{6} I d . \$ 66630$.

7348 U.S. 26 (1954). The Court held that condemnation of a department store for 
by condemning Bay land and paying private owners for their loss. The difficulty of obtaining the requisite funds, however, probably precludes this approach and requires the use of alternative legal tools.

Part II of this Comment discusses one such alternative: enforcement of BCDC's comprehensive plan under the police power, which enables the government to regulate to protect the public health, safety, and morals and further the general welfare without paying compensation. Part II will examine various theoretical attempts to distinguish between "takings" of property, which require compensation, and "regulations" of property, which do not. Criticizing these distinctions, Part II lists factual criteria present in existing case law which appear to control this question, and concludes that restrictions imposed by the BCDC should be deemed regulations, not requiring compensation. ${ }^{8}$

If the police power supports imposition of controls on Bay development, then a second issue, considered in Part III, arises: Will clothing a regional authority with power to regulate the use of land violate the "home rule" provisions of the California constitution? By characterizing certain governmental functions as peculiarly "local" or "municipal," these provisions prevent the state legislature from interfering in affairs constitutionally allocated to local governments. Part III contends that past judicial treatment of the home rule sections indicates that $\mathrm{BCDC}$,

privately undertaken urban redevelopment was a legitimate component of the public welfare for which the power of eminent domain could be constitutionally exercised. "The concept of the public welfare," said Justice Douglas, "is broad and inclusive. . . . It is within the power of the legislature to determine that the commumity slould be beautiful as well as healthy, spacious as well as clean, well-balanced as well as carefully patrolled." Id. at 33 .

${ }^{8}$ Statutes dealing with problems similar to those of San Francisco Bay lave already been adopted by Massachusetts, but judicial review of them has not been conclusive. The powers conferred by the statutes are quite broad. Any person intending to fill or dredge swamps or marslues must notify designated local and state authorities. Local authorities are empowered to recommend such "protective measures as may protect the public interest." Mass. Gen. Laws ANN. ch. 130, § 27A (Supp. 1966). If the state department of public works finds that the project would endanger navigable tidewaters, injure tidal vegetation, $i d$. ch. $91, \S 30$ (1958), or would remove a natural barrier protecting against erosion by the sea, it may prohibit the project. $I d$. ch. 130, \& 27A (West Supp. 1966). In addition, the director of marine fisheries may impose conditions lie deems necessary to protect slellfish or marine fisleries. $I d$. ch. $130, \S 27 \mathrm{~A}$ (West Supp. 1966). Ch. 130, § 27A subjects violators to a maximum $\$ 100$ fine and six months imprisonment.

These provisions were reviewed in Commissioner of Natural Resources v. S. Volpe \& Co., 349 Mass. 104, 206 N.E.2d 666 (1965). Defendant owned 49.4 acres of a 78 acre marsh and was prohibited by the Director of Marine Fisheries from placing fill thereon "in the interest of protecting marine fisheries and inaintaining the ecological components of this estuarine complex." Id. at 106, 206 N.E.2d at 668 . The court disregarded the trial court's finding of no taking as "lacking support in the evidence," announced a confiscation test (unlike California), and remanded the case for evidence on the property's alternative natural uses, assessed valuation, cost to defendant, fair market value restricted and unrestricted, and the cost of the proposed improvements. Id. at 106, 206 N.E.2d at 671 . 
whose authority transcends municipal boundaries and whose responsibilities are truly regional, does not violate home rule.

In the event that either the police power fails to sustain Bay regulation or such regulation by a state-created regional agency violates home rule, an alternative basis for such regional control is still available. Part IV considers this alternative: the exercise by BCDC of the state's tidelands trust power to protect public rights in navigation, fishing and commerce. Part IV concludes that the purpose of BCDC to promote the rational and restrained development of the Bay comes within the purposes of the trust and that BCDC may invoke the trust powers to regulate both publicly and privately held Bay land.

\section{I}

\section{CONSERVATION VERSUS EXPLOITATION OF SAN FRANCISCO BAY}

\section{A. The Bay as a Natural Resource}

San Francisco Bay performs three basic natural resource functions: It supports marine and wildlife; it provides a site for recreational activities; and it strongly influences the climate. The areas of the Bay most vital for supporting marine and wildlife are the salt marshes. Irrigated by tidal flow, these areas bordering the Bay serve as an essential food source for plants and animals. ${ }^{9}$ Unfortunately, these marshes are the area most threatened by development. In 1850, 304 square miles of such marshland encircled the Bay. By 1957 only seventy-eight square miles remained. If reclamation continues at the present rate, all marshland in the Bay will disappear by $1975 .^{10}$

The mudflats, adjacent to the marshes, are also important to the Bay. Covered and uncovered during the tidal cycle, they provide a feeding ground for clams, mussels, worms and other mud-dwellers which are themselves food for fisl and birds. ${ }^{11}$ Because the Bay area is the most extensive salt and fresh water complex on the California coast, ${ }^{12}$ the majority of Pacific Coast migratory shorebirds frequent this region..$^{13}$ If the remaining 45,000 acres of mudflats were removed from tidal action by diking or filling, seventy per cent of these shorebirds might be exterminated. ${ }^{14}$ Development of the mudflats would also deprive the region

${ }^{9}$ H. Harvey, Some Ecological Aspects of San Francisco Bay, Oct. 1966, at 22, 20 (BCDC).

10 See U.S. DeP'T of CoMneree, supra note 1 , at 88.

11 Bay Conservation and Development Comm'n, Marshes and Mud Flats, Oct. 1966, at 4.

12 G. Delisle, supra note 3, at 17.

$13 \mathrm{H}$. Harvey, supra note 9, at 16 .

14 Id. Extermmation of these birds would conflict with national policy contained in the Migratory Bird Treaty with Great Britain, August 16, 1916, 39 Stat. 1702 (1916), T.S. No. 628 (effective December 7, 1916), as amended June 20, 1936, 49 Stat. 1556 (1936), and 
of a major oxygen source by eliminating the mud algae, which produce and expel oxygen into the water and air by their alternate exposure to light and water. ${ }^{15}$

The underwater configuration of the Bay, important to marine and wildlife, would also be affected by sediment deposits resulting from construction in the Bay. ${ }^{16}$ This sedimentation process, called shoaling, smothers bottom life and reduces the visibihty necessary for fish to locate their food. Further, by reducing the churning effect of tidal action, shoaling diminishes the capacity of Bay water to trap oxygen ${ }^{17}$ necessary for waste assimilation and marine life, and impairs the flushing action of the Bay, which is already feeble in the lieavily populated South Bay. ${ }^{18}$

San Francisco Bay supports numerous recreational activities. The annual use of the Bay for hunting purposes, for example, is estimated at 135,000 days; ${ }^{19}$ recreational fishing occupies $2,125,000$ angler-days ${ }^{20}$ and plotograpliy, bird watching and other educational studies total 370,000 days. ${ }^{21}$ Uncontrolled development, by reducing the marsis and mudflat area in the Bay and by impairing the tidal action, would destroy the marine and wildlife necessary for such recreational uses. ${ }^{22}$

Migratory Bird Treaty with Mexico, February 7, 1936, 50 Stat. 1311 (1937), T.S. No. 912 (effective March 15, 1937), and with state policy contained in CaL. Const. art. IV, \& 251/2 . (West 1954), and CaL. Fish \& Garie Code $\$$ 355-56 (West 1958).

Cases involving protection of migratory birds do not clearly indicate what degree of regulation without compensation is justified. Platt v. Philbrick, 8 Cal. App. 2d 27, 47 P.2d 302 (1935), states in a dictum that the property owner inust bear "some damage" which he might "conceivably" suffer from the restrictions imposed by the Fish and Game Code. Bailey v. Holland, 126 F.2d 317 (1942), contains dicta requiring the government to pay if it attempts to do inore than prohibit slaughter of birds, for example, by erecting improvements to lessen harm resulting from the drainage of marshy areas. If Bay regulations simply permitted or prolibited development with a view to preserving inarshy areas, this would constitute something inore than prohibiting slaughter, but something less than erecting improvements. And it is not clear whether such prohibitions on development would constitute "some damage" as contemplated in Platt v. Philbrick. It is therefore unclear from these cases whether restricting development to save the inarshes would require compensation. $C f$. the discussion of the proprietor-mediator test in text accompanying notes 53-65, infra.

15 Bay Conservation \& Development Comm'n, Marshes and Mudflats, Oct. 1966, at 4.

16 For example, a dike constructed in 1908 has changed the depth of one portion of the Bay by 35 feet. B. Smith, The Tides of San Francisco Bay, 35 (1966) (BCDC).

17 Id. at 20.

${ }^{18} \mathrm{An}$ experiment using a hydraulic inodel of the Bay systein demonstrated that contaminants introduced into the South Bay not only failed to travel toward the mouth of the Bay, but actually penetrated in the opposite direction over a 21-day period. Id. at 24-25.

$10 \mathrm{G}$. Delisle, supra note 3 , at 48 .

$20 I d$. at 56 .

21 Id. at 48 .

22 By assigning the dollar value used by federal agencies to appraise various types of user-days, Delisle has estimated the present annual net economic benefit attributable to 
Bay fill reduces the Bay's cooling effect on the region's atmosphere. Water, unlike land, distributes heat throughout its entire mass, not just its surface, thus absorbing the sun's energy more readily than can the land. In addition, water is a better conductor of heat than land, and dissipates heat more rapidly by evaporation..$^{23}$ By reducing the surface areas and volume of the Bay, filling would restrict these heat-reducing functions and increase temperatures in areas near the Bay by five degrees during summer months. ${ }^{24}$

Filling the Bay, by increasing the region's land area, also will have a significant effect on air pollution. Land is slow to release heat during the day, but it gives off large amounts at night. Carbon dioxide and smoke and dust particles, found in ligh concentration over urban areas, absorb this heat. Since this heat transfer occurs at night, the air close to the ground cools as the ground cools. The cooler air remains close to the ground rather than circulating to disperse the pollutants in the warm air above it. Moreover, any pollutant-producing activities taking place on the filled land will further aggravate the problem. ${ }^{25}$

These natural functions of the Bay are usually left unprotected by the political processes directing governmental action and by the economic forces of the marketplace. No powerful constituency defends the Bay as a food source and habitat for wildlife, or as recreation site, or as an. influence on climate. No significant financial return encourages commercial interests to undertake sucl a defense. Thus unprotected, these natural functions are gravely threatened by filling the Bay.

\section{B. Bay Land as a Commercial Resource}

The rapid rate at which the Bay has been filled and developed over past years illustrates its commercial potential. While the most extensive filling of the Bay has been for public facilities like harbors and airports, ${ }^{20}$ private development, despite the high cost of reclamation, ${ }^{27}$ is increasingly

recreational uses of the Bay at $\$ 9,122,800$. This amount, combined with the estimated value of commercial fisheries, $\$ 2,085,000$, gives a total annual value of $\$ 11,207,800$, which could he otherwise produced only by an investment of $\$ 280,195,000$ yielding $4 \%$ annually. Delisle therefore concludes that "the Bay's fish and wildlife resources represent an investment of . . more than a quarter of a billion dollars." Id. at 92-95 (emphasis omitted). He also estimates that recreational users expend an annual total of $\$ 25$ milion. Id. at 95-97.

${ }^{23}$ A. Miller, Smog and Weather, Feb. 1967, at 5-7 (BCDC).

24 Id. at 37-38. Miller thought these changes would become significant before $25 \%$ of the existing Bay surface was elimimated. Id. at 37 . Since $57 \%$ of the Bay's surface is susceptible to reclamation, see Bardwell, Our Vanishing Bay, Part 2, SAN Francisco, March 1965, these changes in weather may soon become a reality in the absence of controlled development.

25 A. Miller, supra note 23 , at $30-31$.

26 U.S. Dep'T of Comanerce, supra note 1 , at 87.

27 The cost of reclaiming land for industrial uses was estimated in 1959 at $\$ 30,000$ 
important..$^{28}$ As available land is developed, expansion into the Bay costs less than the purchase of adjacent, fully developed property.$^{29}$ Further, the current popularity of homes near fishing and boating facilities has made private Bay development attractive.

The Bay is threatened not only by private developers, but also by the previously unbridled generosity of the state legislature, which has granted to various cities the right to build small craft harbors, warehouses, public halls, small shops, bars, restaurants, motels and public parks on stateowned tidelands. ${ }^{30}$ Although the cities have not always responded to this invitation, ${ }^{31}$ they have been encouraged to act in recent years by provisions in the legislative grants which prescribe revocation if the authorized project is not undertaken within a himited period of time. ${ }^{32}$

Unrestrained development for public and private purposes could irretrievably destroy the natural, recreational, and aesthetic values of the Bay. Marine life, wildlife, recreation, and the beauty of the Bay will enjoy the greatest protection if citizens of the region preserve the Bay's natural state, rather than employ Bay land for commercial development.

per acre. This did not include the subsequent cost of improving the land. Id. at 92. Estimates had increased by 1963 to $\$ 30,000-50,000$. Hearings on Filling San Francisco Bay Before the Cal. Assembly Interim Comm. on Natural Resources, Planning and Public Works 13 (San Francisco Cal., Oct. 22-23, 1963).

28 Bay Farm Island, Alameda, for example, is a development planned to accounodate over 15,000 persons in 5,670 housing units on 723 acres of flled tidelands. Fifty-three per cent of the housing units will have direct access to waterways to be used for small boat sailing, swimming and storm drainage. The completed project will have a value of $\$ 177$ million (1964 prices). Development Plan, Jones-Thenn Associates, Civil Engineers, June 1964.

29 U.S. DEP'T of COMTMERCE, supra note 1 , at 87.

30 See generally R. Anderson (Berkeley City Attorney), Legal Aspects of Proposed Waterfront Development in the City of Berkeley and Recoinmendations for Amendment to the Statutory Grant of Tidelands, Feb. 27, 1961, at 8-13.

31 Indeed, some local officials are either unaware that their government holds a grant of tidelands, or are unfamiliar with the purposes of the puhlic trust and the terms of the grant. Staff of Jonnt Legrslative Conom. on Timetands, 1 Californta's Tideland Trusts 45 (1965).

32 See, e.g., ch. 921 [1959] Cal. Stats. 2952, which required that the grant be exercised within 10 years or it would terminate automatically.

The regulatory activity of the $B C D C$ during its first year indicates the pressure for development. The Commission processed thirty permits for fill or excavation and granted twenty-five. Only two of the pernits granted involved solid fill (35 acres) whereas four of the five permits demied involved solid fill (105 acres). Bay Conservation \& Development Comm'n, BCDC Progress Report (1967). These figures exclude 52 minor permits granted for (1) pilings for homes or docks, (2) routine inaintenance dredging around piers and docks, (3) location of utility cables, and (4) pilings and improvements for bridges and roadways; these permits involved filling of less than three acres. $I d$.

This data indicates that a responsible regulatory agency considered two-thirds of all Bay fill plans either (1) unnecessary to the "health, safety, or welfare of the pubhc in the entire bay area," or (2) incompatible with the comprehensive plan being prepared by the Commission. CAL. Gov'T Code $\S 66631$ (d) (West 1966). 
This conflict between preservation of the Bay in its natural state and use of the Bay for development can only be resolved by appraising what is essential to both interests and adjusting them realistically.

This adjustment will probably curtail development more drastically than natural resource functions because regional consequences of limiting development in the Bay will be less severe. While proximity to the Bay is essential for projects hike harbors and marinas, most development may easily be located elsewhere. Equally practicable alternatives, however, cannot be found to counteract the damage caused by development to the Bay. The effects of development on the atmosphere are irremediable. The complex food chain in the Bay can not survive interference. Manmade replacements do not equal marshes and mudflats as a food source and home for marine and wildlife..$^{33}$

The permanent BCDC plan, therefore, may drastically restrict use of Bay land, in some cases prohibiting all development. These prohibitions will force courts to decide whether to require compensation or whether to permit restrictions on development without compensation under the police power. ${ }^{34}$

\section{II}

\section{GOVERNMENTAL REGULATION OF BAY LAND: COMPENSABLE TAKING OR NONCOMPENSABLE REGULATION?}

The fifth amendment commands that "private property [shall not] be taken for public use, without just compensation." ${ }^{35}$ The problem of what constitutes a compensable "taking" of property has long intrigued

33 The contrary view that man can create an environment equal to nature was recently espoused by the Missouri Water Pollution Control Association. Relying solely on cost analysis, the Association proposed that the Missouri River be used for waste disposal and that other means be developed for fish and wildlife propagation, livestock watering, and recreation. The proposal met with strong popular disapproval. The Christian Science Monitor, Feb. 21, 1967, at 11, col. 1 .

34 The extent of the restriction depends on the scope and validity of the property interest, and there are currently two arguments limiting the rights of Bay owners who trace their ownership ultimately to the state or a municipahity. First, if the state's tidelands trust responsibility to protect the pubhic rights of navigation, fishing and commerce applies to private property, the state may substantially curtail the private owner's free utilization of his land. See Part IV, infra. Second, sales into private ownership may be altogether void because of a purchase price below fair value or other defect. See Public Hearing Re: Leslie Salt Company-State Title Clarification Before the State Lands Conmission, San Mateo, Calif., Dec. 8, 1966; M. Scotr, The Future of San Francisco Bay 4 (1963); but cf. Alameda Conservation Ass'n v. City of Alameda, No. 354427 (Super. Ct., Alameda County, Cal., Feb. 8, 1966) (municipal sale of tidelands held to present no triable issue of fact). In order to discuss the taking problem in its strongest light, it is assumed herein that private owners suffer from no such defects in title.

35 See also CAL. Const. art. I, §§ 13, 14 (West 1954). 
scholars ${ }^{36}$ and confounded courts. ${ }^{37}$ Commentators have attempted to order judicial chaos by suggesting analytical or historical distinctions. Courts, on the other hand, have provided a plethora of abstract principles without adopting any clear-cut, generally applicable formula to distinguish between compensable takings and noncompensable regulations.

Because of the factual complexity of regulating Bay Development, the quest for a rehable and generally applicable test to distinguish a taking from a regulation is not helpful. The following discussion therefore suggests that an analysis of judicial responses to fact situations in recent land use cases better indicates whether a compensable taking will be found.

Defining the scope of compensable takings is crucial for successful control of Bay development. If prohibitions on Bay development are permitted only upon payment of compensation, control may be financially impossible. Funds would not be available, either at the state or regional level, to finance comprehensive Bay restrictions. Moreover, by paying compensation, BCDC would become the owner of large amounts of land. The state legislature may not wish to impose the managerial obligations of such ownership upon a regional agency. ${ }^{38}$ Therefore, because the expense and difficulty of administration may preclude control of Bay development if compensation is required, the legislature and $\mathrm{BCDC}$, in order to plan the orderly and most economical development of the Bay, must know whether Bay regulation will constitute a compensable taking.

\section{A. Inadequate Theories}

Four principal theories have been urged for defiming a compensable taking: The invasion theory, the noxious use theory, the proprietormediator theory, and the reasonable exercise of police power theory..$^{39}$ Although satisfactory in part, each enjoys limited usefulness in resolving

${ }^{36}$ For the views of Profs. Dunham and Sax, see text accompanying notes 46-59, infra.

37 Compare Wynehamer v. People, 13 N.Y. 378 (1856) (forbidding sale of liquor deprives liquor owners of property without due process) with Mugler v. Kansas, 123 U.S. 623 (1887) (forbidding sale of liquor does not deprive brewery owners of property without due process).

${ }^{38}$ Such managerial interests might encompass the one-fourth of the Bay which is privately owned. Bay Conservation \& Development Comm'n, BCDC Progress Report (1967).

39 In addition, some courts require compensation if the regulation too greatly diminishes the value of the property or is not prompted by sufficient necessity. These approaehes are not theories but efforts to rest the decision on one particular factual element. Sole reliance on diminution of value is the practice neither of the United States Supreme Court, see Goldblatt v. Town of Hempstead, 369 U.S. 590, 594 (1962), nor of California courts, see text accompanying notes 91-95 infra. Reliance on the degree of necessity was for a while the practice of a few California courts, but not any longer, see note 99 infra. 
questions of uncompensated Bay regulations. The theories may produce dissimilar treatment for similarly situated landowners, their theoretical classifications may break down, or they may be too general in their terms to provide any concrete guideline.

\section{Invasion Theory}

The invasion theory ${ }^{40}$ requires that landowners be compensated when government "invades" their property rights by either taking title to, ${ }^{41}$ or exercising control over, ${ }^{42}$ their property. The theory does not, however, require compensation where the restriction has the same effect as taking title or exercising physical control but is not technically an "invasion." If, for example, the government wishes to provide public parking facilities, it must pay for the land it uses. ${ }^{43}$ Under the invasion theory, however, the government could avoid this expenditure by zoning the private property only for parking. Similarly, if the government purchases property, it must pay the landowner the full value. ${ }^{44}$ The invasion theory, however,

40 The invasion theory was adopted by Chief Justice Parker in Callender v. Marsh, 18 Mass. 417, 429-30, 1 Pick. 418 430-31 (1823) (no compensation to landowner for change in adjacent street level); accord, Smith v. Corporation of Washington, 61 U.S. (20 How.) 135, 149 (1857). But see Gardner v. Newbergh, 2 Johnson 161 (N.Y. ch. 1816) (per Kent, C.) (enjoining village from diverting stream from plaintiff's land). Though the holding of Gardner v. Newburgh rejected the invasion test, its language did not. "A right to a stream of water is as sacred as a right to the soil over which it flows. It is a part of the freehold, of which no man can be disseised [without fair compensation]." Id. at 165.

41 See, e.g., P. Nichors, 3 Emmient Domatn \$ 9.1-.2[5] (3d ed. 1963).

42 E.g., Eyherabide v. United States, 345 F.2d 565 (Ct. Cl. 1965) (compensation required for "physical invasion" from adjacent Navy gunnery range).

43 Vernon Park Realty Co. v. Mount Vernon, 307 N.Y. 493, 121 N.E.2d 517 (1954) (restriction of private property to parking lot use struck down).

44 Kissinger v. City of Los Angeles, 161 Cal. App. 2d 454, 327 P.2d 10 (1958); Krieger v. Planning Comm'n of Howard County, 224 Md. 320, 167 A.2d 885 (1960) (dictum); City of Plainfield v. Borough of Middlesex, 69 N.J. Super. 136, 173 A.2d 785 (L. Div. 1961); Miller v. City of Beaver Falls, $368 \mathrm{~Pa} .189,82 \mathrm{~A} .2 \mathrm{~d} 34$ (1951) (striking down ordinances reducing value of property intended for government purchase). Cf. Smith v. County of Santa Barbara, 243 Cal. App. 2d 126, 52 Cal. Rptr. 292 (1966), in which a change from residential to industrial zoning near a municipal airport was upheld despite the airport's express desire to avoid damage claims from future home owners, and Hunter v. Adams, $180 \mathrm{Cal}$. App. 2d 511, 4 Cal. Rptr. 776 (1966), in which a one year freeze on new construction pending coinunencement of an urban renewal project was upheld. The invasion test is unsatisfactory for the additional reason that, where government restricts nonproperty interests, there is nothing to be "invaded" and therefore compensation need not be paid. In these situations, the invasion test provides an easy path to a hard result. See Umited States v. Central Eureka Mining Co., 357 U.S. 155 (1958).

The invasion theory has displayed a remarkable vitality in United States Supreme Court decisions since the Civil War. It most frequently has been employed to deny compensation. See id. at 165-66 (1958); Pennsylvania Coal Co. v. Mahon, 260 U.S. 393, 417 (1922) (dissenting opinion of Brandeis, J.); Mugler v. Kansas, 123 U.S. 623 (1887) (inter alia); Transportation Co. v. Chicago, 99 U.S. 635, 642 (1878) ; Munn v. Illinois, 94 U.S. 113, 133 (1876). But see Pumpelly v. Green Bay Co., 80 U.S. (13 Wall.) 166, 177-78, 181 (1871) 
would permit the government to pay less by imposing a restriction that diminishes the value of the property to be purchased. In both examples the regulation, through its form, avoids a technical "invasion" and thus deprives the landowner of compensation. ${ }^{45}$ Although courts have usually not tolerated such an abuse, the theory could be used in the Bay to permit regulation or purchase of such public facilities as beaches, harbors, airports, and bridges. Honesty of judicial method therefore requires that the invasion theory be rejected.

\section{Noxious Use Theory}

The noxious use, or creation of harm, theory permits government regulation without compensation of land uses that "cause harm" to the majority of adjacent properties. ${ }^{46}$ Diseased cedar trees, for example, that communicate an infection to apple orchards within a two-mile radius may be destroyed under the noxious use theory without compensation to the owner. ${ }^{47}$ The noxious use theory thus allows regulation of an activity which injures the socially desirable, surrounding majority uses. ${ }^{48}$ This policy oriented analysis is preferable to the technical distinctions of the invasion theory.

The noxious use theory, however, has two weaknesses. First, although it usually indicates which use to restrict, it does not explain why compensation may be denied..$^{49}$ In the Bay, for example, where an industrial

(granting compensation where property "actually invaded" by dam overflow). The Court quoted with approval the invasion theory language of Mugler in its most recent treatment of the taking problem, Goldblatt v. Town of Hempstead, 369 U.S. 590, 593 (1962) (dictum).

45 Sax, Takings and the Police Power, 74 YALE L.J. 36, 46-48 (1964).

46 The creation of harm test is urged by Dunham, Griggs v. Allegheny County in Perspective: Thirty Years of Supreme Court Expropriation Law, 1962 SUPREME CourT Rev. 63, 75, 80, and $A$ Legal and Economic Basis for City Planting, 58 ColuM. L. Rev. 650, 664-67 (1958). For criticism see Heyman \& Gilhool, The Constitutionality of Imposing Increased Community Costs on New Suburban Residents Through Subdivision Extractions, 73 YaLE L.J. 1119, 1128 (1964). The test may have some current influence with the Supreme Court. See Goldblatt v. Town of Hempstead, 369 U.S. 590 (1962) (nature of the menace).

47 Miller v. Schoene, 276 U.S. 272 (1928).

48 See, e.g., Goldblatt v. Hempstead, 369 U.S. 590 (1962); Hadacheck v. Sebastian, 239 U.S. 394 (1915) ; Consolidated Rock Prods. Co. v. City of Los Angeles, 57 Cal. 2d 515, 370 P.2d 342, 20 Cal. Rptr. 638, appeal dismissed, 371 U.S. 36 (1962).

49 Courts may find the test attractive for precisely this reason. By ealling a gravel operation "injurious," the Cabifornia supreme court, for example, could ignore the total destruction of value caused by the operation's complete prohibition. Consolidated Rock Prods. Co. v. City of Los Angeles, 57 Cal. 2d 515, 370 P.2d 342, 20 Cal. Rptr. 638, appeal dismissed, 371 U.S. 36 (1962). Sax criticizes the noxious use theory because, in not seeing the problem as one of "inconsistency between perfectly innocent and independently desirable uses," it mechanically curtails the "evil" or "noxious" use. Sax, supra note 45 at 49 . But this criticism goes too far; the theory at least designates for regulation the single incompatible use or the less numerous of mutually incompatible uses. Sax overlooks these contributions and implies that it would be just as logical to solve the cedar tree problem by pro- 
use producing unpleasant odors and chemical waste is bordered by beach and boating facilities, regulating the industry will disrupt the community less than would terminating or relocating the public facilities. This does not explain, however, why the community may require industry to forego undesirable practices at its own expense.

Second, the noxious use theory fails to solve the problem of two mutually incompatible uses. Increased railroad and highway traffic, for example, makes the crossing dangerous for both trains and autos. Each causes harm to the other; there is no logical way to determine which use is noxious. ${ }^{50}$ Similarly, in the Bay, increased use of swimming and boating facilities in the same vicinity might render each dangerous to the other." Because the noxious use theory does not explain denial of compensation and because it cannot harmonize two incompatible uses, it is inadequate to determine which restrictions on Bay development constitute a taking.

\section{Proprietor-Mediator Theory}

According to the proprietor-mediator theory, if a regulation mediates between competing private forces in the community-for example, by zoning separate areas for residential and industrial use-no compensation is required. But if the regulation promotes some governmental enterprise-for example, by reducing the price of land to be purchased for roads or schools - then compensation must be paid. ${ }^{52}$ Professor Sax, the exponent of the proprietor-mediator test, defends it by saying that it fulfills the historical purpose of the compensation principle-to inhibit arbitrary government action. ${ }^{53}$ Only in acquiring resources for its own use will government tend to that abuse of power which the compensation principle was designed to prevent. ${ }^{54}$ When government simply arbitrates between "competing private economic claims" these dangers will be absent.

hibiting apple orchards in the vicinity. Id. at 49-50. But if a man wants to fire a pistol in his back yard despite encroaching residential development, should that development be restrained so he may have his target practice? Or should restrictions on traffic density be imposed rather than speed limits? The resolution of these conflicting uses is simple under the noxious use test but needlessly difficult under Sax's criticism.

50 The Suprene Court has nevertheless stigmatized railroads as "causing" the harm, thus justifying to its own satisfaction assessnents against the railroad for the cost of improving the crossing. Atchison, T. \& S.F. Ry. v. Public Util. Conm'n, 346 U.S. 346, 353 (1953); Missouri Pac. Ry. v. Onaha, 235 U.S. 121, 130 (1914). But see Nashville C. \& St. L. Ry. v. Walters, 294 U.S. 405, 422-23 (1935) (Brandeis, J.) Justice Holmes reached the same result on the ground that railroads derive the "right" to cross the highway from the state. Erie R.R. v. Pub. Util. Comm'rs, 254 U.S. 394, 410 (1921).

51 See Nelson v. DeLong, 213 Minn. 425, 434-38, 7 N.W.2d 342, 348-50 (1942).

52 Sax, Supra note 45, at 61-76.

53 Id. at 54-60.

$54 I d$. at $64-67$.

$55 I d$. at 62 . Sax recognizes limitations to his approach. "No claim is made that the 
The proprietor-mediator test has two weaknesses. 'First, it fails to deal with government mediation that reconciles a mixture of public and private forces without acquiring resources for government. The location and construction of an airport, for example, might prompt public and private interests adjacent to the Bay to urge stringent regulation or even prohibition of the project, while other private and public interests would exert pressure for the airport. Resolution of this conflict requires government mediation, not between private economic interests as in Sax's test, but rather between mixed public and private interests on eacli side. ${ }^{\mathbf{5 6}}$

This gap in the test might be avoided by reformulating it to require compensation only where the government does acquire resources ${ }^{57}$ regardless of the interests mediated. But this reformulation underlines the second weakness of the proprietor-mediator test: the difficulty of maintaining any significant distinction between inediation and proprietorship. Suppose, for example, that use of airplanes froin a private airport damaged adjacent private property. The proprietor-mediator test would not require a compensation for a regnlation adjusting these two private interests. ${ }^{58}$ Characterizing such a regnlation as mediation, however, is not consistent with the test's original goal of preventing governmental abuse of power. Absence of public ownership does not preclude arbitrary regnlation to ensure a safe, efficient and successful airport. The distinction between resource acquisition and mediation thus fails by not recognizing ways other than resource acquisition by which overzealous government can abuse its powers. Moreover, if compensation hinges on public owner-

enterprise test is a magical formula which will with perfect symmetry solve every conceivable question of government activity which affects the economic status of individuals. Legal problems are simply too diverse and complex for the application of any such umiversal solvents." Id. at 75.

58 Public and private interests joined, for example, to seek BCDC permission for the Port of Oakland to fill 75 acres for a 2,500-foot extension of a runway at the Metropolitan Oakland International Airport. BCDC Application 23-66, denied, July 6, 1967. The public interest for the extension was seen in the increase in safety and the local economic gain from (1) greater fuel and food sales required for longer nonstop flights and (2) the retention of the busmess of larger charter airlines which might shift their operations elsewhere for a longer runway. The private interest for the extension was the benefit to the charter airlines and their customers from carrying more cargo on each flight and avoiding the cost of from $\$ 1,200$ to $\$ 2,000$ which a refueling stop would produce. Id. See also Comment, Land-Use Regulation for the Protection of Public Parks and Recreational Areas, 45 Texas L. REv. 96, 105-06 (1966).

${ }^{57}$ Sax gives as examples of government enterprise the maintenance of armies, roads, schools, buildings and offices, and the acquisition of financial resources for these purposes. Sax, supra note 45 , at 62 .

58 Cf. Smith v. County of Santa Barbara, 243 Cal. App. 2d 126, 52 Cal. Rptr. 292 (1966) (approving change of zone from residential to industrial near airport). But cf. Griggs v. Allegheny County, 369 U.S. 84 (1962); United States v. Causby, 328 U.S. 256 (1946). 
ship, government will be tempted to avoid such payment by initiating public projects under the guise of private enterprise. ${ }^{50}$

Finally, from the landowner's point of view, the same injury is suffered from the restriction whether or not the government, in addition to restricting the land, exacts permission to place public utility lines or conduct some other minimal public activity on the land. Damage to lands adjacent to an airport constructed on Bay fill is the same whether the airport is public or private. But it seems unfair to compensate damaged landowners only because they are adjacent to a public rather than a private airport. The mediator-proprietor test fails as a helpful analytic tool just where the taking problem in Bay regulation will frequently arise.

\section{Reasonable Exercise of Police Power}

The diverse circumstances giving rise to the issue of a taking render impossible the apphication of a general theory distinguishing governmental land use regulations from takings. A less ambitious approach is to determine case by case whether the exercise of the police power is "reasonable." Courts define reasonableness by a variety of abstract principles. They frequently state that the police power, by which government is authorized to control land use to promote the public health, safety, morals and general welfare, ${ }^{60}$ is "elastic." Therefore, if there is a "reasonable basis" for the regulation, ${ }^{62}$ or if the question is "fairly debatable," the courts will

59 The unsatisfactory resolution of the taking problem by the proprietor-mediator test is illustrated by a comparison of two recent cases. In Morris County Land Improvement Co. v. Township of Parsippany-Troy Hills, 40 N.J. 539, 193 A.2d 232 (1963), private swamp land was zoned only for agriculture, certain kinds of government-operated recreation, and facilities for sewage treatment, water supply, and public utilities. Compensation was required, a result which Sax approved. Sax, supra note 45 , at 73. But this result was easily reached under Sax's test because of the government's proprietary interest in the recreational and other public facilities. These elements were absent in Commissioners of Natural Resources v. S. Volpe \& Co., 349 Mass. 104, 206 N.E.2d 666 (1965), in which the government sought to enjoin an owner of marshland from filling the land to the detriment of marine nutrients. The government did not attempt to undertake activitics on the land as it had in Morris County. Under the proprietor-mediator test, compensation need not be paid; the absence of mimor governmental activities, however, is no assurance that the restrictions are less arbitrary. The court remanded the case for further findings. Note 8 supra.

60 E.g., J. Metzenbaum, 1 The Law of Zontang 109 (2d ed. 1955).

61 Village of Euclid v. Ambler Realty Co., 272 U.S. 365, 387 (1926); Miller v. Board of Pub. Works, 195 Cal. 477, 234 P.2d 381, (1925), appeal dismissed, 273 U.S. 781 (1927).

62 Village of Euclid v. Ambler Realty Co., 272 U.S. 365, 395 (1926); Consolidated Rock Prods. Co. v. City of Los Angeles, 57 Cal. 2d 515, 523, 370 P.2d 342, 347, 20 Cal. Rptr. 638, 643, appeal dismissed, 371 U.S. 36 (1962) (reasonable minds miglt differ); Lockard v. City of Los Angeles, 33 Cal. 2d 453, 461, 202 P.2d 38, 42-43, cert. denied, 337 U.S. 939 (1949); Wilkins v. City of San Bernardino, 29 Cal. 2d 332, 339, 175 P.2d 542, 547-48 (1946).

${ }^{63}$ Goldblatt v. Town of Hempstead, 369 U.S. 590, 595 (1962) (dictum); Village of Euclid v. Ambler Realty Co., 272 U.S. 365, 388 (1926); Consolidated Rock Prods. Co. v. 
not look to the "wisdom of the legislation," judgment of the legislature ${ }^{65}$ will leave the regulation intact. While these frequently repeated statements indicate that land use regulations attacked as compensable takings will be upheld whenever possible, they fail to indicate whether specific regulations of Bay development will be struck down. They suggest, for example, that "fairly debatable" legislation will be upheld but provide no factual criteria to determine whether legislation is fairly debatable. ${ }^{66}$ These general statements about the police power enable courts to pay respect to doctrine and yet reach an apparently contrary result. ${ }^{67}$ Occasionally, they permit even members of the same court to reach opposite conclusions while adhering to the same principle. ${ }^{68}$

Not surprisingly, these guidelines may produce confused results. Judicial resolution of taking problems involves sophisticated notions of property ${ }^{69}$ the general welfare, ${ }^{70}$ and the relation between the individual

City of Los Angeles, 57 Cal. 2d 515, 533, 370 P.2d 342, 353, 20 Cal. Rptr. 638, 649 (1962); Lockard v. City of Los Angeles, 33 Cal. 2d 453, 462, 202 P.2d 38, 43 (1949).

64 Lockard v. City of Los Angeles, 33 Cal. 2d 453, 461, 202 P.2d 38, 43; Miller v. Board of Pub. Works, 195 Cal. 477, 490, 234 P. 381, 385-86 (1925).

65 Consolidated Rock Prods. Co. v. City of Los Angeles, 57 Cal. 2d 515, 370 P.2d 342, 20 Cal. Rptr. 638 (1962); Miller v. Board of Pub. Works, 195 Cal. 477, 490, 234 P. 381, 388 (1925); Heyman, Open Space and the Police Power, in Open Space and the Law 7, 11 (Herring ed. 1965).

60 The "fairly debatable" test cannot refer to the mere existence of debate, for then adoption of a regulation followed by a legal attack upon it would uploold the regulation. See Note, 50 CALIF. L. REv. 896, 897 n.9 (1962). If the test means debatable to members of the court, then disagreement among them should always result in upholding the regulation, even though the majority votes otherwise. See also Justice Douglas' criticism of an analogous problem, the "redeeming social value" test for obscenity. Ginzburg v. United States, 383 U.S. $463,489-90$ (1966).

67 See Pennsylvania Coal Co. v. Mahon, 260 U.S. 393, 413 (1922), where the court observed that "The greatest weight is given to the judgment of the legislature" but struck down a statute prohibiting mining. See also Dukeminier, Zoning for Aesthetic Objectives: $A$ Reappraisal, 20 LAw \& CONTEMI. PROB, 218, 223 (1955): "[W]hat courts say and courts do are two different things .... [T] d doctrine [that the police power may not be used for primarily aesthetic purposes] may properly be criticized as meaningless theory, i.e., it does not describe past court response nor enable one to predict future court response."

68 Compare "This is not a question of substituting the judgment of the court for that of the legislature," Lochner v. New York, 198 U.S. 45, 56-57 (1905), with "Under our systems of government the courts are not concerned with the wisdom or pohicy of legislation," id. at 69 (dissenting opinion of Holmes, J.).

69 See, J. Kent, 2 Comamentaries on AMmerican Law *318 (3d ed. 1836): "[T] acquisition and enjoyment of property ... brings all [man's] facilities into exercise, and [enables man] to display the various and exalted powers of the human mind"; Cohen, Transcendental Nonsense and the Functional Approach, 35 CoLoM. I. REv. 809, 816 \& $\mathrm{n} .20$ (1935) (property as a function of inequality); $\mathrm{McDougal}$, The Infuence of the Metropolis on Concepts, Rules and Institutions Relating to Property, 4 J. PUB. L. 93 (1955); Philbrick, Changing Conceptions of Property in Law, 86 U. PA. L. REV. 691 (1938); Reich, The New Property, 73 YaIE L.J. 733 (1964) (property as a function of individuality).

70 See Opinion of the Justices to the Senate, 333 Mass. 773, 778-79, 128 N.E.2d 557, 
and the state. ${ }^{71}$ They resist any logical ordering and application. ${ }^{72}$ Therefore, candid courts and commentators have acknowledged the impossibility of deciding a case solely by the general principles of the reasonable exercise approach. ${ }^{73}$ The reasonable exercise theory can take on meaning only in the factual context of a particular case. To the facts, therefore, we turn.

\section{B. Probable Judicial Response to the Facts of Bay Regulation}

The deceptive quest for certainty solely in general statements of judicial principles is best abandoned. Courts, in determining under the general statements of the reasonable exercise theory whether governmental regulation of Bay development constitutes a "taking" or a "regulation," will focus their attention on the prominent factual elements of Bay regulation. This Part will compare these elements with the controlling factors in prior case law. In particular, the important elements in Consolidated Rock Products Company v. City of Los Angeles, ${ }^{74}$ a leading California case, will be discussed with reference to effective regulation of development in San Francisco Bay. Although this approacli may not

561 (1955). Arnold v. Board of Barber Examiners, 45 N.M. 57, 70, 109 P.2d 779, 787 (1941); Comment, The General Welfare, Welfare Economics, and Zoning Variances, 38 S. Cat. L. Rev. 548 (1965). From a strictly economic point of view, the state would appear justified in imposing on Bay developers the cost of the "external diseconomies," that is, the impairment of natural Bay functions and regional values, which they create. However, it is not yet possible to determine accurately whether regulation will impose on the landowner a loss comparable to the regional diseconomies. See E. Mason, The Political Economy of Resource Use in Perspectives on Conservation 157, 184 (H. Jarret ed. 1958). But see Heyman \& Gilhool, supra note 46, at 1141-46, advocating a cost-accounting technique for allocating subdivision costs.

71 "The great and chief end . . of men's uniting into conmonwealths, and putting themselves under government, is the preservation of their property." J. LOCKE, THE SECOND Treattse on CrvIr Governarent $§ 124$ (1764); Dukeminier, supra note 67, at 224 (society strongly prefers land use to be determined by private volition); Reich, silpra note 69 , at 733 (property defines the troubled boundary between the individual and the state).

72 "The decision [in a concrete case depends] on a judgment or intuition more subtle than any articulate nuajor premise." Lochner v. New York, 198 U.S. 45, 76 (1905) (dissenting opinion of Holmes, J.).

73 "There is no set formula to determine where regulation ends and taking begins," Goldblatt v. Town of Hempstead, 369 U.S. 590, 594 (1962) (dictun1); "[I]f regulation goes too far it will be recognized as a taking. ... [T] [Tis is a question of degree-and therefore cannot be disposed of by general propositions," Pennsylvania Coal Co. v. Mahon, 260 U.S. 393, 415-16 (1922); "[C]ourts have never been able to develop . . . a standard more meaningful than balancing the public need against the private cost," Dunham, supra note 46, at 76; Heyman \& Gilhool, supra note 46, at 1126; Kratovil \& Harrison, Eminent Domain -Policy and Concept, 42 CaLIF. L. Rev. 596, 608-10, 628 (1954).

74 57 Cal. 2d 515, 370 P.2d 342, 20 Cal. Rptr. 638, appeal dismissed, 371 U.S. 36 (1962). 
guarantee predictive certainty, ${ }^{75}$ it offers the most reahistic insights into the judicial process. ${ }^{76}$

Regulation of development in San Francisco Bay presents at least nine potentially siguificant factual elements. Most of these appear in Consolidated Rock Products. There the plaintiffs owned 348 acres of rock, sand and gravel. Excavation and processing of these nuaterials was voluntarily terminated in 1935, and since 1946 the city had denied all applications for the conduct of rock and gravel operations in the immediate vicinity. The plaintiffs, wishing to change the agricultural and residential zoning of the property, applied for its redesignation as a rock and gravel district. The city council denied the application, and the plaintiffs sought an injunction against the enforcement of the agricultural and residential zone. The trial court characterized as "preposterous" the view that the property had any value for these permitted uses: a continuing flood hazard prevented construction of homes and the inferior nature of the soil precluded agriculture. ${ }^{77}$ There was evidence, however, that the rock and gravel operation would create noise and dust that would impair the community's reputation as a haven for sufferers from respiratory ailments and threaten the value of a residential development that had come within one-half mile of the property in recent years. ${ }^{78}$ The trial court therefore upheld the restriction to agricultural and residential uses. This judgment was affirmed by the Supreme Court of California, and the United States Supreme Court dismissed the appeal. The importance of Consolidated Rock Products warrants a detailed discussion of its major factual elements; an appraisal of future permanent Bay regulations will be based on that discussion.

\section{Purpose of the Regulation}

The police power requirement of promoting the health, safety, morals and welfare of the community was met in Consolidated Rock Products. The court approved the legislative policy of protecting residential com-

75 In re J. P. Linahan Inc., 138 F.2d 650, 652-54 (1943). "The chief obstacle to prophesying a trial-court decision is ... the inability ... to foresee what a particular trial judge or jury will believe to be the facts," J. FRANK, LAW AND THE MODERN MIND at xiii (1930). See also S. Hayakawa, Language In Thought and Action 23-68 (2d ed. 1964).

76 "[T] Pennsylvania Coal Co. v. Mahon, 260 U.S. 393, 413 (1922); Ayers v. City Council of Los Angeles, 34 Cal. 2d 31, 41, 207 P.2d 1, 11 (1949); "Each case, of course must stand or fall on its own particular facts," Southern Pac. Co. v. City of Los Angeles, 242 Cal. App. 2d 38, 46, 51 Cal. Rptr. 197, 201 (1966), appeal dismissed per curiam, 385 U.S. 647 (1967). 7757 Cal. 2d at 519, 370 P.2d at 344, 20 Cal. Rptr. at 640.

78 Brief for Appellants at 6, Consolidated Rock Prods. Co. v. City of Los Angeles, 371 U.S. 36 (1962). 
munities from rock and gravel operations and found the restriction consistent with this policy. ${ }^{79}$ Bay restrictions will likewise promote the general welfare. The present enabling legislation of $B C D C$ requires the agency to restraim projects that, by their adverse impact on navigation, natural life, and Bay water and air would be "harmful to the needs of the present and future population of the bay region."180

\section{Comprehensive Regulation}

Courts favor comprehensive land use regulations. ${ }^{81}$ In Consolidated Rock Products, the court emphasized the presence of comprehensive regulations. ${ }^{82}$ The court relied on Village of Euclid v. Ambler Realty $\mathrm{Co} .{ }^{83}$ whose approval of comprehensive zoning indicated that "comprehensive zoning ... had taken its place as a constitutionally recognized part of our legal and political system." ${ }^{\text {"84 }}$ The court leeld that the potential noise and dust from the gravel operation were properly prohibited because " $[t]$ he primary purpose of compreliensive zoning is to protect . . . the general public, from uses of property which will, if permitted, prove injurious to them."185

Bay regulations, like the restrictions in Consolidated Rock Products, should be upheld without the requirement of compensation because the legislature intends their application pursuant to a comprehensive plan. ${ }^{80}$ However, it is not clear what makes a plan comprehensive. The opinion in Consolidated Rock Products, like that in the first California case to uphold a comprehensive regulation, ${ }^{87}$ did not indicate why the zoning

7957 Cal. 2d at 533, 370 P.2d at 353, 20 Cal. Rptr. at 649.

80 CAI. Gov'T CODE $\$ 66601$ (West 1966).

81 Courts believe that comprebensiveness assures thorough investigations and painstaking consideration on the part of the legislature. Village of Euclid v. Ambler Realty $\mathrm{Co}_{\text {., }} 272$ U.S 365,394 (1926). Since zoming may precede planning, this assurance may be false. But where specific regulations are developed from a comprebensive plan, prior deliberations may deter that arbitrary use of power which the compensation principle, Sax, stipra note $45^{\circ}$, at 54-60, and the proprietor-mediator test, see text accompanying notes 52-55 supra, were designed to inhibit. Kozesnik v. Township of Montgomery, 24 N.J. 154, 166, 131 A.2d 1 , 7 (1957). See generally Haar, In Accordance with a Comprehensive Plan, 68 Harv. L. REv. 1154 (1955). 645-47.

8257 Cal. 2d at 520-24, 527-30, 370 P.2d at 345-48, 349-51, 20 Cal. Rptr. at 641-44,

83272 U.S. 365 (1926).

8457 Cal. 2 d at 521,370 P.2d at 346, 20 Cal. Rptr. at 642.

85 Id. at 524, 370 P.2d at 348,20 Cal. Rptr. at 644.

${ }^{80} \mathrm{CAx}$. Gov'T CoDE $\$ 66630$ (West 1966) requires BCDC to "prepare a comprehensive and enforceable plan for the conservation of the water of the San Francisco Bay and the development of its shoreline."

87 Miller v. Board of Pub. Works, 195 Cal. 477, 234 P. 381 (1925), appeal dismissed, 273 U.S. 781 (1927). A Connecticut court has required plans to be "comprehensive as to territory, public needs and time," Fairlawns Cemetery Ass'n v. Zoning Comm'n, 138 Conn. 
was comprehensive. Nevertheless, if the California legislature follows the standards whicl it requires of plans adopted by local agencies, ${ }^{88}$ the plan for regulating Bay development will probably be sufficiently comprehensive. ${ }^{89}$ Moreover, the requirement of a comprehensive plan is not an additional test for determining the validity of land use regulation under the police power but is merely a reformulation of those "considerations which the court must in any case inevitably reach in deciding constitutional issues raised by attackers of the ordinance. $" 190$

\section{Loss of Value, Compensation and Alternative Means}

The restriction upheld in Consolidated Rock Products prevented any productive use of the property but paid the plaintiffs no compensation..$^{91}$ The court's rationale for condoning this total loss of value was far from

$434,439,86$ A.2d 74, 77 (1952), but these general requirements are not helpful outside of specific factual situations.

${ }^{88}$ Local plans must be "Iong-term," CAL. Gov't Code $§ 65300$ (West 1966), and contain (1) "a land use element which designates the proposed general distribution and general location and extent of the use" and (2) "a circulation element consisting of the general location and extent of existing and proposed" transportation facilities, "correlated with the land use element of the plan." Id. $\S 65302$. Additional elements are permitted but not required, including a "conservation element," "community design element" and "such additional elements dealing with other subjects which in the judgment of the planning agency relate to the physical development" of the area. Id. $\S 65303$.

${ }^{89} \mathrm{~A}$ plan including the elements which $\mathrm{BCDC}$ is currently studying would be comprehensive enough. The legislature has instructed BCDC to study:

all the characteristics of bay waters ..., the ecological balance of the bay, and the economic interests in the bay, including the needs of the bay area population for industry and for employment; . . . the study should include the requirements of industries that would not pollute the bay nor interfere with its use for recreation or other purposes, but would need sites near deepwater channels or would need large supplies of water for their manufacturing processes; . . . the study should examine all present and proposed uses of the bay and its shoreline, and should give consideration to the master plans of cities and counties around the bay.

Id. \& 66603. If some considerations have been omitted, that will not prove fatal. A zoning ordinance need not include "every conceivable subject which the legislative authorities might have included in it." Magruder v. City of Redwood, 203 Cal. 665, 672, 265 P. 806, 809 (1928).

The importance of economic considerations for Bay planning is demonstrated by the 1966 application of Humble Oil and Refining Company for approval of certain facilities in Benicia. Denial of the application would have deprived Benicia of the economic benefit of having about 1,000 persons employed in the construction of the refinery and 250-300 local persons employed in the refinery once it began operations. Vallejo Times Herald, May 18, 1966, at 1, col. 7. Bemcia Mayor C. Carsten Johansen wrote the BCDC Executive Director Joseph E. Bodovitz that the economic impact of the refinery defied "short term description." Letter from C. Carsten Johansen to Joseph E. Bodovitz, June 14, 1966.

90 See Haar, supra note 81, at 1172.

01 The United States Supreme Court has approved severe, though not total, loss of value resulting from land use restrictions. Village of Euclid v. Ambler Realty Co., 272 U.S. 365, 384 (1926) (75\% alleged loss); Hadacheck v. Sebastian, 239 U.S. 394, 405 (1915) (93\% alleged loss); $c f$. Mugler v. Kansas, 123 U.S. 623 (1887). 
clear. ${ }^{92}$ The court mentioned only in passing that the land as restricted had no appreciable economic value. Failure to emphasize the loss of value may indicate the unimportance of that factor in California. ${ }^{93}$ Thus the California court, differing from jurisdictions that invalidate regulations according to the diminution of value test, ${ }^{04}$ did not equate total restriction of property with a taking. The court thereby avoided the theoretical difficulty of defining the property involved in order to measure diminished value..$^{95}$

02 The court did not rely on prior California decisions openly countenancing loss of value, presumably because those cases did not involve total loss of value. See Hamer v. Town of Ross, 59 Cal. 2d 776, 787, 382 P.2d 375, 382, 31 Cal. Rptr. 335, 342 (1963) ("'some financial detriment' "); Johnston v. City of Claremont, 49 Cal. 2d 826, 839, 323 P.2d 71, 79, (1958) ("'some hardship' "); McCarthy v. City of Manbattan Beach, 41 Cal. 2d 879, 890, 264 P.2d 932, 938 (1953), cert. denied, 348 U.S. 817 (1954) ("some financial detriment"); Lockard v. City of Los Angeles, 33 Cal. 2d 453, 466-67, 202 P.2d 38, 46, cert. denied, 337 U.S. 939 (1949) ("some hardship"); Wilkins v. City of San Bernardino, 29 Cal. 2d 332, 338, 175 P.2d 542, 547 (1946) ("incidental injury"); Zahn v. Board of Pub. Works, 195 Cal. 497, 512, 234 P. 388, 394 (1925) (depreciation in value not controlling), af'd, 274 U.S. 325 (1927); Miller v. Board of Pub. Works, 195 Cal. 477, 488, 234 P. 381, 385 (1925) ("'incidental damage'"); City of Los Angeles v. Gage, 127 Cal. App. 2d 442, 453, 274 P.2d 34, 40 (1954) ("some hardship").

93 Possible grounds for the court's decision were the prevention of an "injurious" use and the analogy to cases in which a comprchensive zoning ordinance probibiting the extraction of natural products had been upheld. 57 Cal. $2 \mathrm{~d}$ at 524, 529-31, 370 P.2d at 348, 351-52, 20 Cal. Rptr. at 644, 647-48. Or the court may have rehed on the trial court's finding that reasonable minds might differ, id. at 519, 370 P.2d at 345, 20 Cal. Rptr. at 641 , and on the disagreement between the city planning commission and the city council over plaintiffs' application, id. at 519 n.1, 370 P.2d at 345 n.1, 20 Cal. Rptr. at 641 n.1. In reviewing judgments concerning land use regulations, however, California appellate courts are not required to accept the findings of the trial court where the record discloses a reasonable difference of opinion. The appellate court must conduct its own search for "any rational support for the legislative determination." Hanner v. Town of Ross, 59 Cal. 2d 776, 787, 382 P.2d 375, 382, 31 Cal. Rptr. 335, 342 (1963).

94 A familiar formulation of the test is found in Arverne Bay Constr. Co. v. Thatcher, 278 N.Y. 222, 232, 15 N.E.2d 587, 592 (1938): "An. ordinance which permanently so restricts the use of property that it cannot be used for any reasonable purpose goes, it is plain, beyond regulation, and unust be recognized as a taking of the property. The only substantial difference, in such case, between restriction and actual taking, is that the restriction leaves the owner subject to the burden of payment of taxation, while outright confiscation would relieve him of that burden." Accord, e.g., Dooley v. Town Plan \& Zoming Comm'n, 151 Conn. 304, 309-10, 197 A.2d 770, 772-73 (1964); Humthlett v. Reeves, 212 Ga, 8, 90 S.E.2d 14 (1955); Commissioner of Natural Resources v. S. Volpe \& Co., 349 Mass. 104, 206 N.E.2d 666 (1965); Alexander v. City of Minneapolis, 267 Minn. 155, 125 N.W.2d 583 (1963); Morris County Land Improvement Co. v. Township of Parsippany-Troy Hills, 40 N.J. 539, 557, 193 A.2d 232, 242 (1963); Chusud Realty Corp. v. Village of Kensington, 40 Misc. 2d 259, 243 N.Y.S.2d 149 (Sup. Ct. 1963); City of West Univ. Place v. Ellis, 134 Tex. 222, 134 S.W.2d 1038 (1940); cf. Sardino v. Federal Reserve Bank, 361 F.2d 106, 111 (2d Cir. 1966) (loss of $\$ 7,000$ savings account).

05 "If the government floods 80 acres of a 640 , acre farm, is that a total destruction of 80 acres or a nere 121/2 percent loss?" Sax, Taking and the Police Power, 74 YArE L.J. 36, 
The decision in Consolidated Rock Products to impose a total loss of value is particularly noteworthy in light of the equally effective alternative inethods which were available to adjust the conflicting uses. The Los Angeles City Planning Commission Examiner, for example, believed that a complete prohibition of quarrying was not necessary since the operation could be tolerated with the following modifications: that excavation but not crushing be allowed; that all driveways between the plant site and the street be paved to avoid dust; and that all operations be subject to the approval of the Los Angeles County Air Pollution Control District and other interested local agencies. ${ }^{96}$ Although the trial court upheld total prohibition, it agreed that these safeguards could reduce the amount of air pollution below an acceptable standard, reduce noise to a "minimal" level, avoid any "extraordinary" danger to children, and generally permit the rock, sand, and gravel activities to be conducted "with compatibility to adjacent properties and with minimal detriment to the hiving amenities or health conditions of the inhabitants of adjacent properties or in the general area and without probable depreciation in property values to the adjacent properties." ${ }^{\prime 97}$ And the district court of appeal was sufficiently impressed by these alternative methods of regulation to strike down the prohibition in favor of appropriate partial restrictions. ${ }^{08}$ The California supreme court, however, upheld the prohibition despite the availability of effective alternative methods for adjusting the conflicting interests. ${ }^{99}$ The decision signifies a strong preference for

60 (1964). Certainly much greater losses than $12 \mathrm{I} / 2 \%$ have been approved by the courts, see note 91 , supra. The question whether the restricted property is the owner's only asset or just part of extensive land holdings has not been considered by jurisdictions that adopt the dimmution of value test. Sax, supra at 60 . Since petitioner in Consolidated Rock Products never specified the dollar amount of his loss, in terms of either original purchase price or lost future earnings, it is unclear whether the decision may be relied on as approving any total loss of value regardless of amount.

${ }^{08}$ Brief for Appellants at 22, Consolidated Rock Prods. Co. v. City of Los Angeles, 371 U.S. 36 (1962).

$0757 \mathrm{Cal} .2 \mathrm{~d}$ at 519, $20 \mathrm{Cal}$. Rptr. at $640,370 \mathrm{P} .2 \mathrm{~d}$ at 344.

9815 Cal. Rptr. 775 (1961). The appellate court found the restriction particularly distasteful because the property had no alternative uses and the prohibited use could not be undertaken elsewhere. Id. at 781-82.

09 Disregard of existing alternative means indicates an implicit but unmistakable rejection of the necessity test suggested by a few California courts. "In certain circumstances ... the taking or damaging of private property ... is not prompted by so grcat a necessity as to be justified without proper compensation to the owner." Archer v. City of Los Angeles, 19 Cal. 2d 19, 24, 119 P.2d 1, 4 (1941), citing Pennsylvania Coal Co. v. Mahon, 260 U.S. 393 (1922) and Chicago, B. \& Q.R.R. v. Chicago, 166 U.S. 226 (1897). The necessity test of Archer has been followed in House v. Los Angeles County Flood Control Dist. 25 Cal. 2d 384, 388-89, 153 P.2d 950, 951-52 (1944), Clement v. State Reclamation Bd., 35 CaI. 2d 628, 636-37, 220 P.2d 897, 902 (1950), and Hunter v. Adams, 180 Cal.: App. 2d 511, 523, 4 Cal. Rptr. 776, 783-84 (1960). 
affirming the choice of a governing body to impose land use controls of maximum severity without payment of compensation. ${ }^{100}$

Adherence to the preference displayed in Consolidated Rock Products would assure the validity of uncompensated Bay regulations. Initially, it is assumed that Bay controls will absolutely prohibit some development without payment of compensation. But a crucial distinction between Bay regulations and those upheld in Consolidated Rock Products is the absence of alternatives to complete prohibition that protect the Bay equally well. Some devices are admittedly available. These include dredging to prevent shoaling, reopening diked areas to tidal action, deliberately creating marsh lands and mudflats as a habitat for marine and wildlife, and building wherever possible in ways that preserve the natural functions of the Bay. ${ }^{101}$ Financing to meet the costs of these alternatives miglit come from the state, a regional tax, a Bay user fee, or dedicated funds required of developing landowners.

But these alternatives have two shortcomings. First, the functions of the Bay may be too complicated to render any alternatives equally effective. Construction on pilings, for example, while protecting natural life to some extent by permitting tidal action, miglit cause siltation, eventually elevating the habitat above tidal action. Construction over mudflats would also deprive natural life of essential sun. ${ }^{102}$ Moreover, the adverse effects of development on weather and the scenic value of the natural shoreline could probably only be avoided by complete prohibition,

Second, alternative methods are expensive. The cost of construction on pilings, for example, would probably preclude construction in the Bay, particularly when other land is immediately available for development within the region..$^{103}$ Diked areas could be reopened to tidal action only by foregoing activities such as salt extraction behind the dikes. ${ }^{104}$ In-

100 The United States Suprene Court's attitude is similar to that of the California supreme court. In its most recent taking case the Court regarded "the availability and effectiveness of other less drastic protective steps" as only one of several criteria for determining the "reasonableness" of the regulation. Goldblatt v. Town of Hempstead, 369 U.S. 590, 595 (1962).

101 H. Harvey, Some Ecological Aspects of San Francisco Bay, Oct. 1966, at 23-24 (BCDC); R. Stebbims \& H. Mason, The Eneryville Crescent and the Albany-Richmond Mudflats, San Francisco Bay Shore Ecological Study Areas, July 13, 1966, at 14 (submitted to the Land and Water Reserves Comm., University of California, Berkeley).

102 See H. Harvey supra note 101, at 9.

103 Even by the year 2020, land will still be available in the Bay Area for urban development, mostly in the North Bay counties. U.S. Dep'T of Comarerce, Future Developsent of THE SAN Francisco Bay Area 1960-2020 at 72 (1959).

104 The curtailment of salt production to protect the Bay might burden commercial interests in the Bay Area with the importation of salt from the Great Salt Lake in Utah at more than twice the cost of Bay Area salt. See M. Scotr, Tre Future of San Francisco BAT 44 (1963). 
creased dredging would add to an annual cost already estimated at 3 million dollars. ${ }^{105}$ In short, although alternative means are available for reducing the effects of fill and development on the Bay, they would be quite expensive and would not be as effective as total prohibition. Regulation of the Bay is thus unlike regulation of the rock and gravel operation in Consolidated Rock Products where equally effective and economical alternatives to total prohibition were available. Uncompensated regulations should therefore be upheld because the need for them is even greater than in Consolidated Rock Products.

\section{Reciprocal Benefit}

Courts are more tolerant of regulations that benefit land as they restrict it. A required street dedication is more palatable if widening the adjacent street renders the restricted property more accessible. ${ }^{108}$ In Consolidated Rock Products, however, the regulation was upheld despite the absence of any reciprocal benefit to the restricted property. Prohibitions on Bay development, benefiting the surrounding region but usually not the land regulated, should therefore not be struck down for lack of a reciprocal benefit. ${ }^{107}$

\section{Discrimination}

Courts do not favor regulations whose dissimilar treatment of similarly situated properties makes no contribution to the general welfare. ${ }^{108}$ Such regulations are struck down as unjustified discrimination. The charge of discrimination was made by the plaintiffs in Consolidated Rock Products because of the continued operation of an adjacent rock and gravel company. But the court rejected the attack, finding distinctions between the properties which supported the different treatment. Concluding that reasonable minds could differ on the significance of the differences, the court affirmed the decision of the legislature. ${ }^{109} \mathrm{It}$ is assumed that BCDC's

105 B. Smith, Sedimentation Aspects of San Francisco Bay, Oct. 1966, at 35 (BCDC).

108 See Southern Pac. Co. v. City of Los Angeles, 242 Cal. App. 2d 38, 51 Cal. Rptr. 197 (1966), appeal dismissed per curiam, 385 U.S. 647 (1967).

107 Some Bay regulations may produce a reciprocal benefit, for example, where they diminish flooding of both the regulated land and adjacent properties. A restriction with such a reciprocal benefit has been held not to be a taking. United States v. Sponenbarger, 308 U.S. 256, 266-67 (1939). For criticism of the reciprocal henefit approach see Heyman \& Gilhool, The Constitutionality of Imposing Increased Community Costs on New Suburban Residents Through Subdivision Exactions, 73 XALE L.J. 1119, 1128-30 (1964).

108 See, e.g., Hamer v. Town of Ross, 59 Cal. 2d 776, 781-82 382 P.2d 375, 379, 31 Cal. Rptr. 335, 339 (1963), in which the court struck down a one acre minimum size lot requirement as applied to land surrounded by parcels of lesser size.

${ }^{109}$ The court noted that the adjacent operation was smaller than plaintiffs', enjoyed more protection from wind, bore a different relation to nearby development, and was "substantially depleted." 57 Cal. at 532-33, 370 P.2d at 352-53, 20 Cal. Rptr. at 648-49. 
eventual formulation and application of regulations will avoid treating differently properties that are similar unless sucli treatment would promote the regional interest in the Bay. An attack on the regulations for discrimination slould therefore fail.

\section{Flexibility}

Some courts are reluctant to uploold flexible regulations leaving too mucl discretion to the decision making agency. ${ }^{110}$ California courts have not shared this reluctance, ${ }^{111}$ upliolding discretionary authority on two conditions. First, the enabling zoning ordinance or legislation inust clearly authorize the exercise of sucl broad discretionary power. The court will strike down challenged regulatory activity not expressly provided for in the enabling legislation. ${ }^{112}$ Time-consuming curative legislation is then required to state the legislative intent more inclusively. Since such a delay miglit permit irreparable injury to the Bay, legislation conferring permanent regulatory powers upon the BCDC should either expressly grant broad authority to make exceptions to the plan's specific provisions ${ }^{113}$ or sliould consist entirely of stated goals, functional relationships and performance standards rather than specific geographical use designations, leaving implementation to $B C D C .{ }^{114}$ Because the legislature cannot foresee every regulatory possibility, and because specific land use regulations must change with the needs of the region, ${ }^{115}$ California courts uphold sucl statutorily authorized flexibility "to insure the validity" of the reg-

110 See generally Haar \& Hering, The Lower Gwynedd Township Case: Too Flexible Zoning or an Inflexible Judiciary?, $74 \mathrm{HARv}$. L. REv. 1552 (1961).

111 See Case v. City of Los Angeles, 218 Cal. App. 2d 36, 39 n.1, 32 Cal. Rptr. 271, 272 n.1 (1963), which upheld an ordinance authorizing the zoning administrator to impose such conditions "as he finds are necessary to protect the best interests of the surrounding property or neighborhood, ... or to secure appropriate development in harmony with the objectives of the Master Plan"; Wheeler v. Gregg, 90 Cal. App. 2d 348, 203 P.2d 37 (1949); Otis v. City of Los Angeles, 52 Cal. App. 2d 605, 126 P.2d 954 (1942).

112 See Santa Clara County Contractors \& Homebuilders Ass'n v. City of Santa Clara, 232 Cal. App. 2d 564, 43 Cal. Rptr. 86 (1965), and Kelber v. City of Upland, 155 Cal. App. 2d 631, 318 P.2d 561 (1957), in which the courts struck down muricipal exactions for parks and schools as outside the provisions of the Subdivision Map Act, Cax. Bus. \& Pror. CODE 11500 (West 1964); accord, Resen v. Village of Downers Grove, 19 Ill. 2d 448, 167 N.E.2d 230 (1960); Coronado Dev. Co. v. City of McPherson, 189 Kan. 174, 368 P.2d 51 (1962); Haugen v. Gleason, 226 Ore. 99, 359 P.2d 108 (1961). The Cahifornia Legislature responded by broadening the Act's provisions to include park, recreational and school purposes. Cat. Bus. \& Pror. CodE $§ \S 11510,11525.2$ (West Supp. 1966).

${ }^{\prime 113}$ See Note, Land Subdivision Regulation: Its Effects and Constitutionality, $41 \mathrm{ST}$. JoHN's L. REv. 374, 383 (1967).

${ }^{114}$ See Haar \& Hering, supra note 109, at 1574.

115 "Changing conditions necessitate changed regulations. A comprehensive plan of zoning does not mean permanent regulation. Extensions, curtailments, and modifications are all a part of comprehensive zoning." Smith v. Collision, 119 Cal. App. 180, 185, 6 P.2d 277, 278 (1931). 
ulation in its particular application "without substantially impairing its general purpose and intent."116 Delegation of such discretionary power will not be improper, but will be upheld as a "quasi-judicial, or perhaps administrative power." $" 117$

The second requirement of California courts is that discretionary authority be supported by adequate findings of fact. ${ }^{118}$ Findings of fact, like comprehensiveness, are inportant because they ensure legislative deliberateness and prevent arbitrary exercise of power. ${ }^{119}$ Such findings satisfy "the essential requirement of due process" and foreclose judicial interference in the affairs of the regulatory body unless there is a "clear and convincing showing of the abuse of the power of discretion" vested in it. ${ }^{120}$

\section{Aesthetics}

The regulation in Consolidated Rock Products was upheld though it protected no siguificant aesthetic interest. ${ }^{121}$ In other situations where aesthetic considerations are more important, such as billboards, California courts have acknowledged aesthetic interests as justifying uncompensated regulations, although they weaken this recognition by relying also on the economic benefit which the community derives from such regulations. ${ }^{122}$

\footnotetext{
116 Bringle v. Board of Supervisors, 54 Cal. 2d 86, 90351 P.2d 765, 768, 4 Cal. Rptr. 493, 496 (1960).

117 Wheeler v. Gregg, 90 Cal. App. 2d 348, 362, 203 P.2d 37, 46 (1949).

118 Johnston v. City of Claremont, 49 Cal. 2d 826, 838, 323 P.2d 71, 78 (1958); Kappadahl v. Alcan Pac. Co., 222 Cal. App. 2d 626, 35 Cal. Rptr. 354 (1963); Ames v. City of Pasadena, 167 Cal. App. 2d 510, 334 P.2d 653 (1959).

$119 \mathrm{See}$ Greyhound Limes, Inc. v. Public Util. Comm'n, 65 A.C. 865,423 P.2d 556, 56 Cal. Rptr. 484 (1967) (findings of fact required by statute); Haar \& Hering, supra note
} 110 , at 1574 n.70; note 81 supra.

120 Wheeler v. Gregg, 90 Cal. App. 2d 348, 360-61, 203 P.2d 37, 46 (1949).

121 Only the trial court gave aesthetics any consideration, briefly stating that "it is undoubtedly true that an alluvial wash in its natural state is superior to pits therein." Brief for Appellants at 42a, 371 U.S. 36 (1962).

122 Burk v. Mumicipal Court, 229 Cal. App. 2d 696, 702, 40 Cal. Rptr. 425, 428; Metromedia, Inc. v. City of Pasadena, 216 Cal. App. 2d 270, 273, 30 Cal. Rptr. 731, 733 (1963) ; National Advertising Co. v. County of Monterey, 211 Cal. App. 2d 375, 27 Cal. Rptr. 136 (1962); accord, United Advertising Corp. v. Metuchen, 42 N.J. 1, 198 A.2d 447 (1964). But see id. at 8, 198 A.2d at 450 (dissent urging solely aesthetic ground). Other jurisdictions have also used additional grounds for upholding aesthetic zoning. See Moore v. Ward, 377 S.W.2d 881 (Ky. 1964) (acquire federal financial assistance and prevent private exploitation by billboards of publicly constructed highways); St. Louis Gunning Advertising Co. v. City of St. Louis, 235 Mo. 99, 145, 137 S.W. 929, 942 (1911), appeal dismissed per stipulation, 231 U.S. 761 (1913) (billboards proniote immorality). See also McCarthy v. City of Manhattan Beach, 41 Cal. 2d 879, 890, 264 P.2d 932, 938 (1953), cert. denied, 348 U.S. 817 (1954) (prevent imnoral activity).

The sufficiency of aesthetics for exercise of the police power has been much mooted. See, e.g., Dukeminier, Zoning for Aesthetic Objectives: A Reappraisal, 20 LAW \& ConTEMP. Pros. 218 (1955); Rodda, Accomplishment of Aesthetic Purposes Under the Police Power, 
Courts in other states, however, accord increasing weight to aesthetic purposes and uphold uncompensated regulations on aesthetic grounds alone. ${ }^{123}$

Bay regulations, in contrast to the prohibitions upheld in Consolidated Rock Products, will promote a substantial aesthetic interest. The Bay is an outstanding scenic asset. Major highways and bridges expose the Bay at most points to the view of passers-by. Homeowners on the surrounding hillsides take pride in the attractive view which their homesites command. Sportsmen and naturahsts, through intimate contact with the Bay, keenly value its beauty. Moreover, the lure of the Bay benefits local businessmen, who accommodate the tourists it draws, and employers who more easily can attract talented personnel to their Bay Area offices. Such contributions to the general welfare, dependent upon the beauty of the Bay, support the validity of uncompensated Bay regulations. California courts, which are tolerant of community regulatory schemes, ${ }^{124}$ will probably so hold.

\section{Severity of Restriction Compounded by Breadth of Application}

The prohibition upheld in Consolidated Rock Products restricted only one parcel of land. Some adjacent rock and gravel operations had not been similarly proscribed. But because comprehensive restrictions on Bay development will affect hundreds of private owners of Bay land, ${ }^{125}$ a court

27 S. Car. L. Rev. 149 (1954); Sayre, Aesthetics and Property Vahes, Does Zoning Promole Public Welfare?, 35 A.B.A.J. 471 (1949); Comment, Zoning, Aesthetics, and the First Amendment, 64 Corus. L. REv. 81 (1964); Comment, Aesthetic Control of Land Use: A House Built upon the Sand?, 59 Nw. U. L. Rev. 372 (1964).

123 The leading case is Oregon City v. Hartke, 240 Ore. 35, 400 P.2d 255 (1965), in which the city excluded automobile wrecking yards. The court noted the "growing judicial recognition of the power of a city to impose zoning restrictions which can be justified solely upon the ground that they will tend to prevent or minimize discordant and unsightly surroundings" and explained that "it is not irrational for those who must live in a community from day to day to plan their pbysical surroundings in such a way that unsigbtliness is minimized." Id. at $40,42,400$ P.2d at 261, 263.

An important case to hasten the acceptance of aesthetics as an independent justification is People v. Stover, 12 N.Y.2d 462, 191 N.E.2d 272, 240 N.Y.S.2d 734, appeal dismissed, 375 U.S. 42 (1963) (ordinance restricted maintenance of clotheslines), discussed in Comment, Zoning, Aesthetics and the First Amendment, 64 CoLOM. L. REv. 81 (1964). Also, Justice Douglas' declaration in Berman v. Parker, 348 U.S. 26, 33 (1954), that the fifth amendment does not prevent a community from being beautiful as well as sanitary has provided a fertile, though erroneous, source for linking aesthetics to the police power. See Jasper v. Commonwealth, 375 S.W.2d 709, 711 (Ky. 1964); City of Santa Fe v. Gamble-Skogmo, Inc., 73 N.M. 410, 414, 389 P.2d 13, 17 (1964); Oregon City v. Hartke, 240 Ore. 35, 41, 400 P.2d 255, 262 (1966). Berman v. Parker upheld an action in eminent domain, not a regulation without compensation.

124 Rodda, supra note 122 , at 177.

125 GrIFFENHAGEN-Kroeger, Inc., SAN Franctsco Bay TIDEtands Assessed Vatuation and Planned Deveiopmants, a Report to the San Francisco Bay Conservation Study CoMartsston 24-96 (1964). 
might reject the restrictions as falling severely on too many. The potential severity of the restrictions is best illustrated by the sliarp increase in value which development creates for Bay land. In 1964, the assessed valuation of all parcels of Bay land was 5,250,911 dollars. Development plans at that time involved 16,216 acres. If carried out, these plans would increase assessed valuation by $473,250,000$ dollars, ninety-five times the assessed valuation. ${ }^{126}$ Nevertheless, this severity of restriction compounded by breadth of application does not necessarily bar uncompensated regulation. ${ }^{127}$

Moreover, several factors may reduce the loss of value to Bay landowners. First, the generally low current assessed valuations indicate perhaps a low purchase price paid by the present owner and result in relatively low holding expenses through taxes. ${ }^{128}$ Therefore, if lost prior investment rather than lost potential profits are considered, prohibitions on Bay development do not produce a drastic loss for Bay owners. ${ }^{129}$ Second, some landowners whose development is prohibited may be able to put their land to alternative remunerative uses like extraction of mineral resources ${ }^{130}$ or shells. ${ }^{131}$

Third, total prohibitions of development will be evaluated in the context of the entire plan for regulating the Bay. The preponderance of various nonprohibitory regulatory devices certain to be included in the plan will make any particular prohibition less harsh to the court. ${ }^{132}$ Probably the prevalent form of regulation will be authorization of development but under specified conditions. The experience of BCDC has

$126 I d$, at $1-2$.

127 This conclusion assumes the nonapplication of the dimimution of value approach. In Mugler v. Kansas, 123 U.S. 623 (1887), the Supreme Court upheld a state constitutional amendment prohibiting the manufacture of intoxicating liquors and thus rendered valueless the brewing facilities of manufacturers throughout the state.

128 "It is evident that the assessors regard the tidelands as idle land with little immediate value." GrIFFENHAGEN-KROEGER, INc., supra note 125 , at 2. Questionable title may be an additional factor mitigating actual loss. See note 34 , supra.

129 Current assessed valuation and purchase price have, with other factors, been deemed relevant in a diminution of value jurisdiction for deciding the taking question. Commissioner of Natural Resources v. S. Volpe \& Co., 349 Mass. 104, 108, 206 N.E.2d 666, 671 (1965).

130 See F. Goldman, Salt, Sand and Shells (Jan. 1967) (BCDC).

181 See, e.g., BCDC Application 17-66 by Ideal Cement Company for permission to dredge oyster shells for use in producing cement.

132 [W] hen a particular restriction is a part of a comprehensive zoning system, other reasons may be found for sustaining it than would be the case if it stood alone as a restriction independently imposed. If the general plan, of which the particular restriction is an integral part, bears a definite and clear relationship to the wellestablished purpose of the police power, then the argument may well be made that the validity of the individual restriction may be based, not alone on its immediate relation to health, safety, morals, and general welfare, but as part of, and in furtherance of, a general plan designed to foster those ends.

Women's Kansas City St. Andrew Soc'y v. Kansas City, 58 F.2d 593, 604 (8th Cir. 1932). 
already proved such an approach fruitful in accommodating both the private interest of the developer and the regional interest of the public, ${ }^{138}$ and the imposition of such conditions has been readily upheld in California..$^{134}$

An important recent case upholding conditions exacted in exchange for permitting development indicates the factors which a court might consider in upholding Bay regulations. In Southern Pacific Company v. City of Los Angeles, ${ }^{135}$ the landowner sought a permit to construct a warehouse on his property. Before granting the permit, the city required him to dedicate a portion of his property for widening streets in accordance with the city's master plan for community development. ${ }^{130}$ The district court of appeal, in upholding the requirement, injected two novel but crucial considerations into the review of land use controls. First, the court noted that some 1,104 voluntary dedications had already been made; second, it relied on testimony that use of eminent domain would take

133 For example, the BCDC granted a dredging permit to a developer on the condition that public paths be provided on at least $65 \%$ of certain levees, that public open space be provided and necessary financial commitments be made, and that certain marshlands be sold to an appropriate public agency. BCDC, Minutes of Meeting, November 18, 1966, at 5.

134 California courts may uphold required conditions on the theory that development creates a need for which the government can require a dedication, Ayres v. City Council of Los Angeles, 34 Cal. 2d 31, 41, 207 P.2d 1, 7 (1949), or on the more sweeping theory that enjoyment of benefits from improvement to land is a "privilege" that may be conditioned, Southern Pac. Co. v. City of Los Angeles, 242 Cal. App. 2d 38, 47, 51 Cal. Rptr. 197, 202 (1966), appeal dismissed per curiam, 385 U.S. 647 (1967); City of Buena Park v. Boyar, 186 Cal. App. 2d 61, 67, 8 Cal. Rptr. 674, 679 (1960); cf. Jordan v. Village of Menomonee Falls, 28 Wis. 2d 608, 137 N.W.2d 442, 448 (1966). Both theories are applicable to Bay development.

The privilege theory was used as early as 1895 to secure dedication of public streets in exchange for the "privilege" or recording a subdivision plat. Ross v. United States ex rel. Goodfellow, 7 App. D.C. 1, 10-11. For criticism of the theory, see Heyman \& Gilhool, supra note 107, at 1130 .

A challenging extension of the privilege theory has been suggested by Marion Clawson, former head of the Federal Bureau of Land Management. M. Clawson, Why not Sell Zoning and Rezoning (legally, that is), CRY CALIFORNIA, Winter 1966-1967 at 9. He points out that zoning for intensive development or rezoning for a higher use imcreases its value without requiring the owner to pay for the benefit so conferred. Therefore Clawson suggests that public authorities offer for sale in open competitive bidding the zoning classifications permitting the use they desire. Specific conditions could be enforced by the contract of sale. The reclassification would go to the highest bidder. Clawson acknowledges that certain problems might attend such a practice, but claims that open bidding for zoning classification would accomplish two desirable goals: First, by making public the valuecreating process now occurring behind the scences, open competitive bidding would ensure fairness of treatment to all applicants; second, sale of zoning classification would return to the public treasury some of the values which public zoning creates for private lands.

135242 Cal. App. 2d 38, 51 Cal. Rptr. 197 (1966), appeal dismissed per curiam, 385 U.S. 647 (1967).

${ }^{138}$ The required dedication constituted $0.1 \%$ of the entire property or $6 \%$ of the portion to be developed. 
more than 100 years because of lack of sufficient public funds. ${ }^{137}$ The question of a taking thus shifted from whether the government ought to pay to whether the government had successfully foregone payment in the past ${ }^{138}$ and whether it could afford to pay if so required.

These criteria provide a substantial buttress to regulation of Bay development. A large number of landowners will certainly comply from the outset because they will be permitted to utilize their land by meeting relatively mild conditions. Moreover, eminent domain with regard to the Bay will cost more because the extensive restrictions will far exceed the small requirement which the city could not pay for in Southern Pacific. ${ }^{139}$ Moderated by the presence of required conditions less stringent than a total prohibition, the harshness of Bay regulations compounded by the large number of affected landowners should not lead a court to strike the regulations down.

\section{Balancing Benefit against Detriment}

Courts reviewing land use regulations weigh the benefit produced by the regulations against the detriment incurred. In Consolidated Rock Products, for example, the court declared that the prohibition served "the best interest and general welfare of the community as a whole."140 Once satisfied with the relation between benefit and detriment, courts uphold the regulation as "fairly debatable" or as one on which "reasonable minds could differ." Although no factual analysis can indicate with certainty whether a court will find that Bay regulations serve the general welfare of the whole region, examination of the relevant considerations does afford some basis for prediction.

The regional benefits of comprehensive regulation of the Bay have already been discussed..$^{141}$ Briefly, they include the protection of wildhfe, enlrancement of recreation, preservation of the Bay's beneficial influence on climate, retention of the aesthetic value of the Bay, and the added efficiency which derives from orderly growth. Private detriment in some instances results from denial, without payment of compensation, of any property use at all. In other instances, private detriment results from

137 Id. at 48,51 Cal. Rptr. at 203.

138 The significance of substantial prior compliance was recognized in Brous v. Smith, 304 N.Y. 164, 167, 106 N.E.2d 503, 505 (1952), and Headley v. City of Rochester, 272 N.Y. 197, 203, 5 N.E.2d 198, 200-01 (1936).

139 There is a contrary argument that the more drastic Bay regulations are accompanied by the greater resources of the Bay region or even the state, which will enact the controls; but whether such resources are in fact proportionately greater than the resources of the City of Los Angeles is not the question. The Court in Southern Pacific looked not to total resources but only to available resources.

14057 Cal. 2d at 533, 370 P.2d at 353, 20 Cal. Rptr. at 649.

141 See text accompanying notes $9-25$ and preceding note 124 supra. 
required conditions or dedications imposed on development. A possible regional detriment may also arise from the loss of facilities which would otherwise develop in the Bay. These might include waterfront residences, marinas, transportation and other commercial facilities, and industry. The loss of these facilities may cause inconvenience or harm to the public which they would have served. ${ }^{142}$ For the following reasons, however, a court will probably not find that the private and regional detriments are incommensurate with the benefits gained and, therefore, will uphold the regulations as serving the general welfare of the region.

First, the values protected by Bay regulations are substantial. Part I of this Comment showed that damage from unrestricted use to the Bay's wildlife, recreational opportunities, climate, and scenic value will not be lightly felt by the residents of the region. Second, damage to the Bay in the absence of effective regulations would be irreparable. This distinguishes Bay regulations from those upheld in Consolidated Rock Products, in which quarrying could have been authorized and later prohibited with no permanent damage to the surrounding community. But once a portion of the Bay is filled, it cannot be unfilled. Once a scenic area is destroyed, it cannot be retrieved. And once the delicate network of natural life in the Bay is upset, it may be out of joint forever.

Third, the balance of benefit versus detriment must be viewed in the long run. If the regional interest in the Bay does not restrain development now, development will gradually destroy regional interests later. The question, therefore, is not simply whether regional interests justify the immediate and substantial curtailment of development. The question is more precisely this: whether regional interests should be permitted to impose a sharp curtailment on development now rather than permitting development to impose a less perceptible but equally substantial curtailment of regional interests. There is no way for both interests to escape injury; one will be sacrificed to the other, or they will be adjusted for maximum harmony. The legislature, by creating $\mathrm{BCDC}$, has chosen the latter course. Viewed in the long run, it appears to serve the general welfare of the entire region.

\section{Summary}

Part II has explored several theories for distinguishing takings from regulations and has found them unhelpful in determining whether uncompensated regulation of development in San Francisco Bay will be

142 The regional detriment from lost development is more acute in regions where the pressure for land is greater. For a discussion of this problem in New York City, see Note, Effect of the Navigation Servitude on Land Reclamation, 2 Cocus. J.L. \& Soc. PROB. 75 (1966). 
upheld. Therefore, the factual elements of Bay regulation have been analyzed in light of prior cases and the conclusion has been reached that Bay regulations will be upheld. Total prohibitions on development will be only one facet of a comprehensive and flexible scheme of controls resolving the conflict between the natural values of the Bay and development and producing a substantial contribution to the general welfare of the region. Regulation of Bay development under the police power should withstand judicial scrutiny.

\section{III}

\section{STATE CONSTITUTIONAL PROBLEMS-HOME RULE}

Part I of this Comment described the natural functions of the Bay and explored the threat to them from Bay development. Part II discussed whether a permanent regional agency could use the police power to resolve this conflict by enforcement of a comprehensive, effective regional plan. The prediction was made that such enforcement would be valid.

But this conclusion does not surmount all the legal obstacles facing an agency like BCDC. Standing squarely in the Commission's path are the home rule provisions of the California constitution. ${ }^{143}$ Strongly worded to protect municipalities from an interfering state legislature, these provisions initially appear fatal to any legislative attempt to resolve the problems of uncontrolled development in San Francisco Bay. ${ }^{144}$ The critical sections deny the legislature power to create special corporations or commissions interfering with municipal activities, reserve "Inunicipal affairs" exclusively to cities with charters, and authorize all cities to exercise the police power unless it is "in conflict with general laws."

\footnotetext{
143 CaL. Const. art. XI, $\S \S 6,8,11,12,13$, and art. IV, $\S 25$ (33) (West 1954). Discussion of art XI, $\S 12$, a home rule provision denying the legislature the power to tax for mumicipal purposes except through the mumicipalities themselves, has been omitted on the assumption that regulation of Bay development will not require expenditure of large sums of money which the legislature might prefer to derive locally. Should this assumption prove incorrect, however, and the legislature vests in a permanent regional agency like the BCDC a power to tax, such a power would not violate $\S 12$, whose prohibition extends only to taxation for "mumicipal purposes." See Santa Barbara County Water Agency v. All Persons, 47 Cal. 2d 699, 708-09, 306 P.2d 875, 881 (1957), rev'd on other grounds sub nom. Ivanhoe Irrigation Dist. v. McCracken, 357 U.S. 275 (1958), modified, 53 Cal. 2d 743, 350 P.2d 100, 3 Cal. Rptr. 348 (1960), discussed in text accompanying notes 148-52 infra.

144 The home rule provisions do not apply to that part of the Bay clearly subject to the state's authority as trustee of the Bay for the benefit of public navigation, fishing and commerce. Mallon v. City of Long Beach, 44 Cal. 2d 199, 209, 282 P.2d 481, 487 (1955). The home rule provisions challenge a state created regional agency where state jurisdiction under the tidelands trust is unclear, namely, over lands privately owned. These private lands constitute $25 \%$ of the Bay, Bay Conservation \& Development Comm'n, BCDC, Progress Report (1967); their exemption from state control under the home rule provisions would render ineffective any regional regulatory scheme. Whether the state's authority as trustee covers these private lands is discussed in Part IV.
} 
The problems presented by California's home rule provisions are not unique. Twenty-five other states have similar constitutional or statutory provisions differing only in their particular operation. ${ }^{145}$ These states could encounter difficulties whenever their legislatures act to achieve rational use of land and water, reduction of air pollution, rehabilitation of inner cities, or development of rapid metropolitan transportation. These problems might be held to be "municipal functions" or "affairs," completely removed from legislative control by state constitutional home rule provisions.

California courts have not applied the constitution's home rule provisions literally, thus avoiding unwise restriction of the legislature's power. Part III of this Comment examines the interpretations by which California courts have reconciled the apparent limitations of the home rule provisions with the needs of a fast growing state and appraises the probable judicial response to the regulatory activity of a permanent, legislatively created agency like BCDC. ${ }^{\mathbf{1 4 6}}$

\section{A. Prohibitions Against Special Corporations and Commissions for Municipal Purposes and Functions}

The home rule provisions most troublesome for the legislative establishment of an agency to regulate land use in San Francisco Bay are sections 6 and 13 of article XI.

\section{Corporations for "Municipal Purposes": Article XI, Section 6}

Article XI, section 6, provides that "[c]orporations for municipal purposes shall not be created by special laws." BCDC might be attacked under this section on two grounds: that it serves a "municipal purpose," and that it was created by a "special law." But interpretation of these sections by the Cahifornia supreme court disposes of these contentions. In Santa Barbara County Agency v. All Persons, ${ }^{147}$ the legislature created

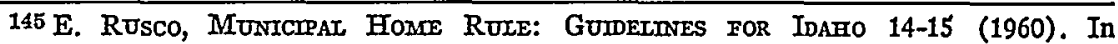
California, the responsibility for determining the scope of charter city home rule rests with the courts, who must in every case give content to the phrase "municipal affairs." In other states, the legislature plays a more decisive role. First, the legislature may make absolute grants to cities of specific areas of authority, like determining penalties for violation of municipal ordinances. Second, the legislature may grant cities the residual power to act in all areas, regardless of their local or statewide nature, so long as they are not withheld from municipal control by a charter prohibition or state statute. A. van Alstyne, Background Study Relating to Article XI: Local Government 252-59 (Cal. Const. Revision Comm'n 1966).

146 The issue of BCDC's constitutionality under the home rule provisions has been raised in litigation but lias not yet been fully determined on the merits. People v. Town of Emeryville, Civil No. 358253 (Super. Ct., Alameda County, Cal., Aug. 21, 1967) (holding for Emeryville on other grounds), in San Francisco Chronicle, Aug. 22, 1967, at 4, col. 1.

14747 Cal. 2d 699, 306 P.2d 875 (1957), rev'd on other grounds sub nom. Ivanhoe 
by law an agency to supply water to the county of Santa Barbara. The agency was challenged as serving a "municipal purpose." The court dismissed the objection, reasoning that the agency transcended the boundaries of any one municipality and was not, therefore, a corporation for a "municipal purpose."148 Supported by other California autlority, ${ }^{140}$ this conclusion is implicit in the legislature's statement that municipalities and existing water districts could not solve the water problems of the entire county without regional assistance. ${ }^{150} \mathrm{BCDC}$ should be found valid for the same reason: Bay problems, which local governments are unable to solve, transcend municipal boundaries. ${ }^{151}$

\section{Commissions to Perform "Municipal Functions": Article XI, Sec- tion 13}

The most difficult challenge to regional regulatory agencies is posed by section 13 of article XI. The section provides that:

The Legislature shall not delegate to any special commission, private corporation, company, association or individual any power to make, control, appropriate, supervise or in any way interfere with any county ... or municipal improvement, money, property, or effects, whether held in trust or otherwise, ... or perform any municipal function whatever.

The BCDC's power to prohibit Bay filling migltt be deemed to interfere with potential municipal improvements like construction of streets and public buildings. A prohibition on fill might also engage BCDC in the

Irrigation Dist. v. McCracken, 357 U.S. 275 (1958), modified, 53 Cal. 2d 743, 350 P.2d 100, 3 Cal. Rptr. 348 (1960).

$148 \mathrm{Ch} .1501, \S 17$, [1945] Cal. Stats. 2801. Because the court found that the agency, by the scope of its responsibilities, had not been created for a "municipal purpose," it did not have to face the "special law" objection.

Article IV, $\S 25$ (33) of the constitution contains an additional prohibition on special laws: no local or special laws shall be passed "where a general law can be made applicable." This section should not hinder $B C D C$, however, because the unique problems of the Bay could not be solved as well by a statervide agency. BCDC will satisfy the judicial requirement that a special law's classification have a "'substantial relation to the purpose for which the legislation was designed." Sacramento Municipal Util. Dist. v. Spink, 145 Cal. App. 2d 568, 572, 303 P.2d 46, 51 (1956); accord, Powers Farms, Inc. v. Consolidated. Irrigation Dist., 19 Cal. 2d 123, 119 P.2d 717 (1941); San Bernardino County v. Way; 18 Cal. 2d 647, 117 P.2d 354 (1941); Solvang Mumcipal Improvement Dist. v. Jensen, 111 Cal. App. 2d 237, 240-41, 244 P.2d 492, 494 (1952).

149 City of Pasadena v. Chamberlain, 204 Cal. 653, 660-61, 269 P. 630, 633 (1928); County of Los Angeles v. Hunt, $198 \mathrm{Cal}$. 753, 774-75, 247 P. 897, 905 (1926). See notes 152-81 and acconpanying text for a discussion of what constitutes a "municipal function" under art. XI, § 13 .

$150 \mathrm{Ch} .1501, \S 17$, [1945] Cal. Stats. 2801.

151 See CAI. Gov't CoDE $\$ 66601$ (West 1966). See the discussion of whether BCDC's responsibilities constitute a "municipal affair" over which charter cities have exclusive power, in text accompanying notes 182-201 infra. 
municipal function of land use control and planning. ${ }^{152}$ Nevertheless, the following discussion will show that section 13 of article XI does not prevent this exercise of BCDC's power. Striking down BCDC on section 13 grounds would contradict the historical purpose of the section. Further, it would abandon the established doctrines of "larger municipality" and "statewide purpose" which California courts have used to uphold legislative activity against section 13 attacks. ${ }^{153}$

(a) History Leading to Enactment of Section 13.-In the years preceding the adoption of section 13 , the legislature frequently intervened in local affairs ${ }^{154}$ through acts, for example, directing cities to pay the claims of designated individuals, ${ }^{155}$ issue bonds without voter approval, ${ }^{150}$ and levy taxes and spend money for various purposes. ${ }^{157}$ In addition, the legislature appointed commissions free of local control with power over municipal indebtedness and taxation. ${ }^{158}$ Nonfiscal forms of interference

152 Various aspects of land use control have been deemed "municipal affairs" for purposes of CAI. ConST. art. XI, $\$ \S 6,8(\mathrm{j})$. Cases cited note 201 infra.

153 An additional ground for defeating a $\$ 13$ challenge is the "Iocal option" or "Iocal consent" doctrine, which validates legislatively created agencies that operate only with the approval of local residents or their local representatives. City of Whittier v. Dixon, 24 Cal. 2d 664, 667, 151 P.2d 5, 7 (1944); Housing Authority v. Dockweiler, 14 Cal. 2d 437, 463, 94 P.2d 794, 807-08 (1939); Butterworth v. Boyd, 12 Cal. 2d 140, 82 P.2d 434 (1938); In re Pfahler, 150 Cal. 71, 88 P. 270 (1906); Davies v. City of Los Angeles, 86 Cal. 37, 24 P. 771 (1898); Wilson v. Board of Supervisors, 154 Cal, App. 2d 101, 110-11, 315 P.2d 748, 754-55 (1957) ; Mesmer v. Board of Pub. Service Comm'rs, 23 Cal. App. 578, 138 P. 935 (1913). See van Alstyne, supra note 145, at 328; Peppin, Municipal Home Rule in California: IV, 34 CALIF. L. REv, 644, 684-87 (1946) [hereinafter cited as Peppin IV]. While the operation of BCDC is not conditioned upon local consent, local interests are well represented on the Commission. Twelve of the Commission's twenty-seven members are popularly elected local officials (or their chosen representatives); the other memhers are chosen from widely diverse federal, state and local interests. CAL, Gov'T CoDE \& 66620 (West 1966). This substantial local representation and the broad spectrum of independent and frequently conflicting interests provide built-in protection against unilateral legislative intervention. The spirit of the consent doctrine, therefore, if not the letter, would be served by upholding BCDC.

${ }^{154}$ See generally Peppin, Municipal Home Rule in California: I, 30 CAIIr. L. REv. 1, 6-22 (1941) [hereinafter cited as Peppin I].

155 E.g., ch. 8, [1859] Cal. Stats. 6 (directing payment of the claim of Moses Scott for $\$ 1,000)$; ch. 78, [1869-70] Cal. Stats. 78 (directing payment of the claim of James S. Houseman to extent of $\$ 1,200$ ).

150 E.g., ch. 618, [1877-78] Cal. Stats. 957 (directing San Francisco supervisors to issue $\$ 43,500$ school bonds).

157 E.g., ch. 78, [1862] Cal. Stats. 66 (ordering San Francisco to spend $\$ 1,300$ for the completion of an additional story to the fire departanent's engine house); ch. 307, [1860] Cal. Stats. 286 (ordering Sacramento to levy taxes to support the State Agricultural Society).

158 E.g. ch. 88, [1851] Cal. Stats. 387 (designating for San Francisco the "Commissioners of the Funded Debt"); ch. 486, [1869-70] Cal. Stats. 711 (authorizing the governor to appoint a commission to determine the validity of certain contracts and assessments for street work in San Francisco). 
also vexed the municipalities. Commissions created by the state legislature were given control of the fire department ${ }^{159}$ and other public works like streets and parks. ${ }^{160}$ The courts were slow to afford relief from such interference. ${ }^{101}$ During the Constitutional Convention of 1878 indignation at these highhanded legislative practices was vehemently expressed. ${ }^{162}$ Section 13 was the solution produced by the Convention for these abuses. ${ }^{163}$

The primary purpose of section 13 was apparently to prevent legislative interference in the fiscal affairs of municipalities. ${ }^{164}$ This conclusion gains implicit support from the Supreme Court of California, which has used section 13 to strike down only legislation affecting matters of local finance ${ }^{105}$ while sustaining legislation affecting nonfiscal matters. ${ }^{100}$

$\mathrm{BCDC}$ is not involved in local finance, having no authority over local funds or bonds. Its sole responsibilities are to conduct a detailed study of

109 E.g., ch. 513, [1877-78] Cal. Stats. 796.

160 E.g., ch. 570, [1875-76] Cal. Stats. 856 (authorizing the governor to appoint a board to control public works in Los Angeles).

161 Peppin I, sulpra note 154, at 22-34. The courts espoused the theory that the municipalities were creatures of the legislature and therefore had no cause to complain of legislative intervention in nunicipal affairs. Not until 1875 did the California supreme court depart froin this position. People v. Lynch, 51 Cal. 15 (1875) (state legislature may not validate illegal municipal assessments).

162 One delegate deinanded:

Why should the Legislature force upon you inen ... [who] control your funds and pay off your debts? Why should not the local authorities do it? Why slrould the Legislature appoint the Conmissioners? Why should the Legislature appoint a Commission to go into any city or county in this State to do any act which the [cities] can better do theinselves, and better supervise themselves? ... We bave had Commissions put upon us by the Legislature, down in San Francisco, to open streets at an enormous expense, amounting often almost to a confiscation of property-some even had to give up their property. I hope it will be stopped.

2 Debates and Proceedings of the Constitutional Convention of the State of CALIFornia 1066 (1881).

103 The section liad been taken almost verbatim from art. III, $\S 20$, of the Pennsylvania constitution, adopted in 1873. Id.

104 Peppin IV, supra note 153, at 682.

105 In Yarnell v. City of Los Angeles, 87 Cal. 603, 25 P. 767 (1891), the legislature, by enactment of the city charter, authorized the city treasurer to contract annually for the deposit of city funds with the private bank offering the most favorable terms. The court held that this authorization violated the prohibition of $\S 13$ against legislative acts which "in any way interfere with any ... city ... money." $87 \mathrm{Cal}$ at $607,25 \mathrm{P}$. at 767. In City of Los Angeles v. Teed, 112 Cal. 319, 44 P. 580 (1896), the court relied on Yarnell to invalidate bonds issued pursuant to a state statute that resulted in making an out-of-state bank the agent of the city for the bonds. In the most recent case finding a violation of $\& 13$, Merchants Nat'l Bank v. Escondido Irrigation Dist., 144 Cal. 329, 77 P. 937 (1904), the court struck down a statute which permitted the board of directors of an irrigation district to mortgage district property as security for its bonds. The court found a violation of $\$ 13$ because, in the event of foreclosure and sale, control over the water system would effectively be delegated to the purchaser.

${ }^{166}$ See cases cited notes 170-79 infra and accompanying text. 
the Bay for conservation and development ${ }^{187}$ and to issue or deny permits for any project involving filling or dredging of the Bay. ${ }^{188}$ Money for these activities is not derived locally but is provided by legislative appropriations from the state general fund. ${ }^{169}$ Because the cases in which a section 13 violation has been found each involved local financial responsibilities not exercised by $\mathrm{BCDC}$, they provide no basis for striking down $\mathrm{BCDC}$ on section 13 grounds. ${ }^{170}$

(b) The "Larger Municipality" and "Statewide Purpose" Doctrines.Cases upholding legislative action against a section 13 challenge recognize that the section was intended to prohibit only legislation interfering with purely local matters. Special commissions have been upheld if they either fulfill a more than local purpose, under the "larger municipality" doctrine $^{171}$ or promote a "statewide purpose."172 Where an agency's responsibihities extend beyond the boundaries of a single town, filling a wider need, the "larger municipahity" doctrine will uphold it. ${ }^{178}$ Where the agency's activities are related to the responsibilities of state government; the "statewide purpose" doctrine will uphold it, ${ }^{174}$ even if the agency exercises less than statewide jurisdiction. ${ }^{175}$ The supreme court recently

167 Cax. Gov't Code $\$ 66603$ (West 1966).

168 Id. \$ 66604 (West 1966).

$169 \mathrm{Ch} .1162, \S 2$, [1965] Cal. Stats. 2946.

170 The Pennsylvania constitutional provision from which $\S 13$ was taken has similarly been applied only to interference with local financial policy. Trantner v. Allegheny County Authority, 316 Pa. 65, 173 A. 289 (1934); Krasnowiecki \& Paul, The Preservation of Open Space in Metropolitan Areas, 110 U. PA. L. Rev. 179, 211 n.107 (1961).

171 City of Pasadena v. Chamberlaim, 204 Cal. 653, 269 P. 630 (1928); Doyle v. Jordan, 200 Cal. 170, 190-92, 252 P. 577, 586-87 (1926); Henshaw v. Foster, 176 Cal. 507, 169 P. 82 (1917); Pixley v. Saunders, 168 Cal. 152, 141 P. 815 (1914). See Brooks, The Metropolis, Home Rule, and the Special District, 11 Hasrangs L.J. 246, 248-50 (1960). Though these cases involved districts formed by local consent, the courts did not rely on this factor to uphold them.

172 Joint Highway Dist. v. Hinman, 220 Cal. 578, 32 P.2d 144 (1934). Metropohtan Water Dist. v. Burney, 215 Cal. 582, 11 P.2d 1095 (1932).

178 Pixley v. Saunders, $168 \mathrm{Cal} .152,141$ P. 815 (1914). A sanitary district encompassing several mumicipalities was formed pursuant to general authorizing legislation, ch. 161; [1891] Cal. Stats. 223, and was uplield as not performing a mumicipal function. The court recounted the difficulties posed by financing, condemnation, and repair of separate sanitary facilities for each town and came "inevitably to the conclusion that while generally the question of sanitation is a municipal affair, in many instances it is one of broader scope, which cannot be adequately handled by the mumicipal authorities of a single town." 168 Cal. at 160, 141 P. at 818 . For the same reasons, the court in People v. City of Los Angeles, 179 Cal. App. 2d 558, 4 Cal. Rptr. 531 (1960), avoided the $\S 13$ prohibition against municipal improvenents.

174 People v. City of Los Angeles, 179 Cal. App. 2d 558, 566, 4 Cal. Rptr. 531, 536 (1960).

175 Fellonı v. Redevelopment Agency, 157 Cal. App. 2d 243, 320 P.2d 884, appeal dismissed, 358 U.S. 56 (1958). 
stressed the purpose and "total effect" of the legislation. ${ }^{176}$ It acknowledged that challenged "legislation may impinge upon local control to a limited extent"177 but did not consider this infringement unconstitutional in light of a statewide purpose. ${ }^{178}$ One court lias stated flatly that mere enactment of a statute by the state legislature demonstrates a sufficient statewide purpose to avoid section $13 .^{179}$

This analysis suggests that regulation of Bay development will be upheld on the basis of both "larger municipality" and "statewide purpose." The complex functions of the Bay transcend the boundaries of any single municipality and lack of adequate protection from local governments. The Bay suffers from the problems of multiple jurisdictions and conflicting governmental policies underlying the "larger municipality" doctrme..$^{180}$ Moreover, forceful constitutional and statutory declarations of state interest in conserving water resources ${ }^{181}$ make the statewide purpose doc-

176 Professional Fire Fighters, Inc. v. City of Los Angeles, 60 Cal. 2d 276, 294, 384 P.2d 158, 169, 32 Cal. Rptr. 830, 841 (1963). The court was faced with challenges based on $\S \S 6$, $8,8 \mathrm{~T} / 2,12$ and 13 of art. XI. The diminishing importance of these arguments is reflected in the court's dismissal of these objections, not elaborately one by one, but briefly together.

177 Id. at 295, 384 P.2d at 169, 32 Cal. Rptr. at 841 .

178 Accord, People v. City of Los Angeles, 179 Cal. App. 2d 558, 567, 4 Cal. Rptr. 531, 537 (1960) (state condemnation of city park land for highway purposes).

179 Fellom v. Redevelopment Agency, 157 Cal. App. 2d 243, 247, 320 P.2d 884, 887 (1958); cf. Peterson v. Board of Supervisors, 65 Cal. App. 670, 674-75, 225 P. 28,30 (1924) (reclamation district). But cf. City of Redwood City v. Moore, 231 Cal. App. 2d 563, 42 Cal. Rptr. 72 (1965) (local improvement district enacted pursuant to statute held municipal affair). Fellom considered the fact of state enactment also sufficient to defeat a challenge under art. XI, $\S \S 6,8(j)$. See discussion in text accompanying notes 182-201 infra.

180 San Mateo County, for example, has a master plan not binding on its cities. South San Francisco has a plan to which private plans do not conform. In the East Bay, some plans assume that construction of a new freeway will fill in present tidelands, other plans do not make this assumption, and still others are awaiting a more definite location of the freeway route. Griffentagenn-Kroeger, Inc., San Francisco Bay Tidelands Assessed Valuation and Pzanned Developaments, a Report to the San Francisco Bay Conservarros Study Comnassros 3 (1964). These planning conflicts result from diffuse ownership of the Bay and a lack of uniform government control. The Bay is in the hands of hundreds of private owners, twenty cities, three counties, one harbor district, the state of Califorma, and the federal government. See id. at 24-96. See generally StafF of Jonnt Legrslative Comas. on Tmetands, 1 Catifornda's Tmberand Trusts (1965). Each entity has its own proprietary interest; each contributes to the lack of uniform control which the legislature intended to cure by creating $\mathrm{BCDC}$.

[T]he present uncoordinated, haphazard manner in which the San Francisco Bay is being filled threatens the bay itself and ... no governmental mechanism exists for evaluating individual projects as to their effect on the entire bay; and . . . further piecemeal filling of the bay may destroy the irreplaceable feeding and breeding grounds of fish and wildlife in the bay, may adversely affect the quality of bay waters and even the quality of air in the bay area, and would therefore be harmful to the needs of the present and future population of the bay region.

Cax. Gov't Code $\$ 66601$ (West 1966).

181 Cax. Const. art. XIV, $\& 3$ (West 1954); CAI. Water Code $\S 100$ (West 1956); 
trine applicable. The Commission should, therefore, survive a section 13 attack.

\section{B. Municipal Affairs: Article XI, Sections 6 and $8(j)$}

The second major home rule obstacle to a regional agency created by the legislature to control San Francisco Bay development is found in article XI, sections 6 and $8(\mathrm{j})$ of the California constitution. These sections give charter cities the power to "make and enforce all laws and regulations in respect to municipal affairs, subject only to the restrictions and limitations provided in their several charters."182 These sections prevent the state legislature from interfering in the "municipal affairs" of charter cities. ${ }^{183}$ The San Francisco Bay area contains seventeen charter cities having this autonomy in "municipal affairs."184 If regulation of filling and dredging in San Francisco Bay is a "municipal affair," then a statecreated regional agency like BCDC is forbidden to carry on these functions. The facts of Bay regulation and the case law involving "municipal affairs" support the conclusion that such regulation is not a "municipal affair" for the purposes of article XI, sections 6 and $8(j)$, and, therefore, that $\mathrm{BCDC}$ is not an invalid legislative interference with the autonomy of charter cities.

Filling and other activity in the Bay have consequences extending beyond municipal boundaries. The legislature, aware of these regional

CAL. WATER CODE $\S \S 13000-00.1$ (West Supp. 1966). Moreover, reclamation districts, which carry on much more extensive activities than the BCDC with regard to water and land use, have been specifically exempted from the prohibitions of $\S 13$ by a 1914 amendment. Therefore the prohibitions of $\S 13$ may not apply to the BCDC if it is held to quahify for analogous treatment. Although CAI. Gov't CoDE § 38901 (West Supp. 1966) expressly authorizes cities to reclaim public and private lands and characterizes such projects as local improvements and municipal affairs, the section also states that it shall not affect any public entity, such as BCDC, exercising similar powers.

182 The only difference between these two sections with regard to mumicipal affairs is that $\S 6$ of its own force grants charter cities autonomy over municipal affairs, while $\S 8(j)$ provides that it is competent (but not mandatory) for city charters to provide for autonomy in mumicipal affairs. This difference seems to bave little practical importance, either because of the direct operation of $\S 6$ or because city charters contain express language granting autonomy in municipal affairs. A. van Alstyne, supra note 145, at 191-92.

The difficulties presented by the term "municipal affairs" were foreseen in California from an early date. In Ex Parte Braun, 141 Cal. 204, 74 P. 780 (1903), Justice McFarland described "municipal affairs" as "loose, undefinable, wild words," which imposed upon courts "the almost impossible duty of saying what they mean." He wisely predicted that "in the future each case involving the question will be decided on its own facts, without an attempt at generalization." $1 d$. at 209, 74 P. at 784 (concurring opimion).

183 Butterworth v. Boyd, 12 Cal. 2d 140, 82 P.2d 434 (1938); Cramer v. City of San Diego, 164 Cal. App. 2d 168, 330 P.2d 235 (1958).

184 State Controller, annuat Report of Financtad Transactions, Concernano Cities of Cactrornta 1-3 (1965). 
consequences, ${ }^{185}$ has attempted with $\mathrm{BCDC}$ to create an agency enjoying the broad jurisdiction and power necessary to meet the regional need. California courts, reviewing legislation under sections 6 and $8(j)$, have in two ways displayed a sensitivity to extramunicipal consequences ${ }^{186}$ and to the legislative purpose ${ }^{187}$ in determining whether a particular governmental function is a "municipal affair."

First, California courts have acknowledged the need for uniform regulation extending beyond municipal boundaries. ${ }^{189}$ For example, the supreme court recently upheld legislation affording firemen a right to organize, althougl the legislation infringed on the autonomy of the city board of fire commissioners. ${ }^{190}$ The need for uniform control of filling and dredging in the Bay is similar to the need for "uniform labor practices throughout the state."191 Rational utilization of the Bay and its continued

185 Cal. Gov't CoDE $\$ \S 66600-03$ (West 1966).

186 Professional Fire Fighters, Inc. v. City of Los Angeles, 60 Cal. 2d 276, 294, 384 P.2d 158, 169, 32 Cal. Rptr. 830, 841 (1963); City of Redwood City v. Moore, 231 Cal. App. 2d 563, 577, 42 Cal. Rptr. 72, 84 (1965).

187 Cases cited note 186 supra.

188 Van Alstyne has characterized judicial techniques for determining "municipal affairs" as "pragmatic" and "policy-oriented" efforts "to allocate the governmental powers under consideration in the most sensible and appropriate fashion as between the local and state legislative bodies." A. van Alstyne, supra note 145, at 241, 239.

188 Charter cities have been permitted exclusively to regulate those activities whose impact is limited to the municipality and inay therefore be treated differently by different cities. See, e.g., City of Glendale v. Trondsen, 48 Cal. 2d 93, 308 P.2d 1 (1957) (sewage project); Ainsworth v. Bryant, 34 Cal. 2d 465, 211 P.2d 564 (1949) (taxes for revenue purposes); Raisch v. Myers, 27 Cal. 2d 773, 167 P.2d 198 (1946) (assessment for inunicipal street improvenient); Silver v. City of Los Angeles, 217 Cal. App. 2d 134, 31 Cal. Rptr. 545 (1963) (rubbish collection); Adler v. City of Culver City, 184 Cal. App. 2d 763, 7 Cal. Rptr. 805 (1960) (manner of ordinance enactment) ; Dynamic Industries Co. v. City of Long Beach, 159 Cal. App. 2d 294, 323 P.2d 768 (1958) (city contracting procedures); Wiley v. City of Berkeley, 136 Cal. App. 2d 10, 288 P.2d 123 (1955) (selection of firehouse site); Dairy Belle Farms v. Brock, 97 Cal. App. 2d 146, 217 P.2d 704 (1950) (purchasing practices); Smith v. City of Glendale, 1 Cal. App. 2d 463, 36 P.2d 1083 (1934) (water supply).

Activities which would not of thenselves be considered a "municipal affair" may be so designated by the legislature. City of Redwood City v. Moore, 231 Cal. App. 2d 563, 42 Cal. Rptr. 72 (1965)) (reclamation); Modesto Irrigation Dist. v. City of Modesto, 210 Cal. App. 2d 652, 27 Cal. Rptr. 90 (1962) (location, construction and maintenance of power poles).

190 Professional Fire Fighters, Inc. v. City of Los Angeles, 60 Cal. 2d 276, 384 P.2d 158, 32 Cal. Rptr. 830 (1963).

191 Id. at 295,384 P.2d at 169, 32 Cal. Rptr. at 841 . For the difficulty of achieving comprehensive and coherent control apart from a specially authorized regional agency, see Scott, Major Metropolitan Studies and Action Programs in California, in Metropolman California 21, Governor's Cosmo's on Metropolitan Area Probiems (E. Engelbert ed. 1961). Scott describes the San Francisco Bay Area as "the most complex, decentralized and diffuse" governmental system in the State of California. Id. at 22. See generally J. BoLlens, The Problem of Governafent in the San Francisco Bay Region (1948). 
contribution to the region depend upon its preservation and regulation as a unit. The legislative findings and declarations in the statute creating $\mathrm{BCDC}$ show that the legislature, aware of the danger to the Bay from the the "present uncoordinated, haphazard" treatment of the Bay, intended through BCDC to achieve uniform treatment for the Bay. ${ }^{102}$ The extramunicipal impact of activity in the Bay and this clear legislative statement of purpose should demonstrate to a court that regulation of Bay filling and dredging by a regional state-created agency is not a violation of the constitutional reservation to charter cities of "municipal affairs."103

Second, where both state and charter city have a legitimate interest in different aspects of the same problem, courts have not hesitated to designate the subject both a "municipal affair" and a "statewide concern" in order to uphold the regulations. Thus, a charter city's control over its fire department has been acknowledged but subjected to state-imposed labor standards, ${ }^{104}$ the variety of "games of chance" has permitted the designation of gambling as both "a municipal affair and of statewide concern," ${ }^{105}$ and the construction of a fence around a reservoir has been exempted from mininum wage legislation as a "municipal affair" yet subjected to state limitations on employment of aliens on public works. ${ }^{100}$

This concurrent municipal affair-statewide concern approach is applicable to regulation of filling and dredging in San Francisco Bay. Insofar as these activities affect the entire Bay, the legislature may appropriately empower a regional agency to control this development. But this control does not completely replace the power of local governments to undertake land use planning for their community. The legislature, recognizing that minor projects in the Bay lack regional significance, excepted them from the formal hearing process and authorized their approval independent of the specified regional criteria. ${ }^{107}$ Moreover, $\mathrm{BCDC}$ is required to "coor-

102 Cal. Gov'T CODE $\$ \$ 66600-01$ (West 1966).

103 This conclusion is supported by a long line of California cases loolding activities not to be "municipal affairs" if they produce effects outside the municipality. In re Hubbard, 62 Cal. 2d 119, 396 P.2d 809, 41 Cal Rptr. 393 (1964); Pacific Tel. \& Tel. Co. v. City \& County of San Francisco, 51 Cal. 2d 766, 336 P.2d 514 (1959); Eastlick v. City of Los Angeles, 29 Cal. 2d 661, 177 P.2d 558 (1947); Pipoly v. Benson, 20 Cal. 2d 366, 125 P.2d 482 (1942); Bay Cities Transit Co. v. City of Los Angeles, 16 Cal. 2d 772, 108 P.2d 435 (1940); Young v. Superior Court, 216 Cal. 512, 15 P.2d 163 (1932); Wilson v. City of San Bernardino, 186 Cal. App. 2d 603, 9 Cal. Rptr. 431 (1960); County of San Mateo v. City Council, 168 Cal. App. 2d 220, 335 P.2d 1013 (1959); Cralle v. City of Eureka, 136 Cal. App. 2d 808, 289 P.2d 509 (1955); In re Shaw, 32 Cal. App. 2d 84, 89 P.2d 161 (1939). 104 Professional Fire Fighters, Inc. v. Moore, 60 Cal. 2d 276, 384 P.2d 158, 32 Cal. Rptr. 830 (1963).

105 In re Hubbard, 62 Cal. 2d 119, 396 P.2d 809, 41 Cal. Rptr. 393 (1964).

196 City of Pasadena v. Charleville, 215 Cal. 384, 10 P.2d 745 (1932).

197 Car. Gov'T CoDE $\S 66632$ (d) (West 1966). By the end of 1966, fifty-two such projects had been approved by the Conmission. Bay Conservation \& Development Comm'n, BCDC Progress Report (1967). 
dinate its planning for the bay with planning for the land area surrounding the bay by local agencies, which shall retain the responsibility for land use planning"188 and, in processing permit applications, to give "full consideration to the report of the city council or board of supervisors."199 The legislature, in creating $\mathrm{BCDC}$, attempted to preserve the autononiy of local planning in a manner consistent with essential regional criteria. The legislature recognized that development in San Francisco Bay is partly a municipal affair and partly a state concern. ${ }^{200}$ BCDC should therefore not be found to violate the "municipal affairs" provisions of article XI, sections 6 and $8(\mathrm{j})$ of the California constitution. ${ }^{201}$

\section{Municipal Regulations Limited only by General Law: Article XI, Section 11}

A final home rule provision does not pose a significant obstacle to a legislatively-created agency like BCDC. Section 11 of article XI of the California constitution authorizes "any county, city, town or township [to] make and enforce within its limits all sucli local, police, sanitary and other regulations as are not in conflict with general laws." Because land use regulations are an exercise of the police power and therefore governed by section $11,{ }^{202}$ the question arises whether municipalities will be subject

198 CAL. Gov'T CODE $§ 66631$ (West 1966).

109 Id. \& 66632(c) (West 1966).

200 State financing for BCDC further demonstrates state concern. See Southern Cal. Roads Co. v. McGuire, 2 Cal. 2d 115, 121, 39 P.2d 412, 415 (1934).

201 California cases do not clearly indicate whether BCDC's power to prohibit fill and construction interferes with a municipal affair. An early case states that "the construction of improvennents upon private property within a city is not a municipal affair." May v. Craig, 13 Cal. App. 368, 369, 109 P. 842, 843 (1910). However, this may not be the contemporary view. See Lindell Co. v. Board of Permit Appeals, 23 Cal. 2d 303, 310-11, 144 P.2d 4, 8-9 (1943) (procedure for granting building permits is a "nunicipal affair"); O'Loane v. O'Rourke, 231 Cal. App. 2d 774, 783, 42 Cal. Rptr. 283, 288 (1965) (adoption of general plan is purely local and not of statewide concern); Fletcher v. Porter, 203 Cal. App. 2d 313, 21 Cal. Rptr. 452 (1962); Hunter v. Adams, 180 Cal. App. 2d 511, 518-19, 4 Cal. Rptr. 776, 781 (1960) (granting or denying of building permits is a "municipal affair"); cf. Brougher v. Board of Pub. Works, 205 Cal. 426, 437, 271 P. 487, 492 (1928). $A$ court may reconcile this line of authority with a decision upholding a state-created regional regulatory agency, however, by employing the municipal affair-statewide concern approach. Moreover, the statements that land use regulation constitutes a "municipal affair" are not precedent for BCDC because they were not nuade in the face either of state legislation or of an increasing need as far beyond municipal control as the problens of San Francisco Bay. "[T]he constitutional concept of municipal affairs is not a fixed or static quantity. It changes with the changing conditions upon which it is to operate." Pacific Tel. \& Tel. Co. v. City \& County of San Francisco, 51 Cal. 2d 766, 771, 336 P.2d 514, 517 (1959).

202 Hurst v. Burlingame, 207 Cal. 134, 277 P. 308 (1929); Dwyer v. City Council of Berkeley, 200 Cal. 505, 253 P. 932 (1927); Fourcade v. City \& County of San Francisco, 196 Cal. 655, 238 P. 934 (1925); Miller v. Board of Pub. Works, 195 Cal. 477, 234 P. 381 (1925); City of Stockton v. Frisbie \& Latta, 93 Cal. App. 277, 270 P. 270 (1928); A.C. 
to the control of BCDC because their regulations "conflict" with those of the Commission. An examination of the application process reveals that, in the event of contrary decisions by BCDC and the local government, a "conflict" would arise, and section 11 would override municipal or county exercise of power at that point. Before BCDC holds hearings on an application for a permit, the applicant must first apply for a permit with the municipality or county if it so requires. The local governing body makes its decision, which is transmitted to the Commission. The Commission then makes its own determination, giving "full consideration" to, but not bound by, the local decision. ${ }^{203}$ To the extent of any "conflict" when the Commission's determination differs from the local decision, the power of the city or county is limited by section $11 .^{204}$ An additional objection might be that section 11 is an exclusive grant of the police power to cities and counties, ${ }^{205}$ so that, if a permanent plan for Bay development is enforced with penal sanctions by a regional agency, it would violate section 11. But this argument applies only to agencies which can set the penalty in their own discretion. ${ }^{206}$ If the legislature fixes the penalty and provides the Commission with adequate primary standards by which to promulgate specific regulations, violation of section 11 will be avoided. ${ }^{207}$

Blumenthal \& Co. v. Cryer, 71 Cal. App. 668, 236 P. 216 (1925). Section 11 gives all municipalities the power within their geographic limits to legislate on all appropriate objects of the police power. McKay Jewelers, Inc. v. Bowron, 19 Cal. 2d 595, 600, 122 P.2d 543, 546 (1942); Jardine v. City of Pasadena, 199 Cal. 64, 68, 248 P. 225, 226 (1926) ; In rc Kazas, 22 Cal. App. 2d 161, 165, 70 P.2d 962, 964 (1937).

203 CaL. Gov't CODE $\S 66632$ (b) (c) (d) (West 1966).

204 An objection that BCDC is not part of the "general laws" under $\S 11$ and therefore cannot curtail the local exercise of police power would not find support in the cases, which have dealt mainly with laws that either circumscribe local power without simultaneously substituting state power or which deal with the "municipal affairs" of charter cities. Peppin, Municipal Home Rule in California III: Section 11 of Article XI of the California Constitution, 32 CAIIF. L. REV. 341, 369-76 (1944) [hereinafter cited as Peppin III]. More difficult problems under $\S 11$ than those posed by BCDC arise when a state statute treats the same or substantially the same problem as a inunicipal ordinance but lacks a clear preemptive intent. California courts usually resolve the conflict in favor of the state statute, looking not only to its language, but also to its scope and purpose and to the general pattern of state regulation. A. van Alstyne, Background Study Relating to Article XI: Local Government 302-04 (Cal. Const. Revision Comm'n 1966); see, e.g., In re Lane, 58 Cal. 2d 99, 372 P.2d 897, 22 Cal. Rptr. 857 (1962); Abbott v. City of Los Angeles, 53 Cal. 2d 674, 349 P.2d 974, 3 Cal. Rptr. 158 (1960); Agnew v. City of Los Angeles, 51 Cal. 2d 1, 330 P.2d 385 (1958). But see In re Hubbard, 62 Cal. 2d 119, 396 P.2d 809, 41 Cal. Rptr. 393 (1964). See generally Montgomery, State Pre-emption and Local Legislation, 4 Santa Clara Lawyer 188 (1964); Comment, The State v. The City: A Study in Pre-emption, 36 S. CaL. L. Rev. 430 (1963).

205 Peppin III, supra note 204, at 358.

206 Gilgert v. Stockton Port Dist., 7 Cal. 2d 384, 60 P.2d 847 (1936); In re Werner, 129 Cal. 567, 575, 62 P. 97, 100 (1900) (concurring opinion).

207 Moore v. Municipal Court, 170 Cal. App. 2d 548, 556-58, 339 P.2d 196, 200-01 (1959). 


\section{Summary}

The foregoing discussion suggests that $\mathrm{BCDC}$, empowered to use regional criteria to grant or deny applications for development in San Francisco Bay, does not infringe upon local spheres of activity protected by California home rule provisions. California courts have realistically resisted any mechanical or categorical approach to the adjudication of home rule problems, understanding that certain needs requiring a governmental response do not stop at the city limits. Courts sustain extramunicipal arrangements by which the state legislature meets these needs. The BCDC, as one such legislative effort, will unquestionably be upheld in the face of an attack based on the home rule provisions of the California constitution.

\section{IV}

\section{TIDELANDS TRUST}

The tidelands trust, existing at common law, imposes on the state the obligation to protect the public rights of navigation, fishing and commerce in all tidelands. If the purposes of BCDC come within these trust responsibilities of the state, the Commission's authority would be justified by this public trust, independent of the police power and immune from home rule attacks. The following discussion explores the extent to which the tidelands trust supports regulation by a state-created agency of filling and dredging in San Francisco Bay. ${ }^{208}$

\section{A. Removal From the Trust}

Under English common law the king owned all rights to the sea; the people, however, had a right to use all tidelands for fishing and navigation. ${ }^{200}$ The king was forbidden to grant any interest in the tidelands in derogation of these public rights. ${ }^{210}$ The common law of tidelands in the United States is closely linked to these historical concepts. The public rights to tidelands are protected by each state, ${ }^{211}$ which holds title in trust for the people of the state to "enjoy the navigation of the waters,

208 "Tidelands" in the following discussion indicates submerged lands as well as land covered and uncovered by the tides. See San Pedro, L.A. \& S.L.R.R. v. Hamilton, 161 Cal. 610, 119 P. 1073 (1911).

200 R. HaIL, AN Essay on the Rights of the Crown and the Printegges of the SUBJECT IN THE SEA-SHORES OF THE REALM 45-47 (1830).

$210 \mathrm{~J}$. Angett, a Treatise on the Right of Property in Tide Waters and in the SoIL AND SHORES THereof 24-25 (2d ed. 1847).

211 Shively v. Bowlby, 152 U.S. 1 (1893); Illinois Cent. R.R. v. Illinois, 146 U.S. 387, 452 (1892); Weber v. Board of Harbor Comm'rs, 85 U.S. (18 Wall.) 57, 65 (1873); Pollard's Lessee v. Hagan, 44 U.S. (3 How.) 212, 229 (1844) ; Martin v. Waddell, 41 U.S. (16 Pet.) 366, 410 (1842); Forestier v. Johnson, 164 Cal. 24, 127 P. 156 (1912). 
carry on commerce over them, and have the liberty of fishing therein freed from the obstruction or interference of private parties."212

The grant to BCDC of broad and effective authority over filling and dredging may be valid on the theory that the Commission will fulfill the state's responsibility to protect navigation, fishing and commerce. An initial, minor issue is whether regulation of filling and dredging constitutes protection of navigation, fishing and commerce. The necessity of $\mathrm{BCDC}$ approval for airport fill or harbor or bridge construction and $\mathrm{BCDC}$ 's protection of the Bay as a fish habitat appear to be within the trust purposes for which the state is responsible. ${ }^{213}$

A more significant and difficult question is whether the $\mathrm{BCDC}$ may exercise public trust responsibility over lands which have been removed from state control. Over the years, portions of the Bay have been sold by the state into private ownership and other portions have been granted to local public entities. ${ }^{214}$ This alienation of lands held in trust was permitted at English common law ${ }^{215}$ and has long been upheld by state and federal courts as to both private owners and public grantees. Under certain circumstances, the uses to which such land is put are valid though they do not protect the public interest in navigation, fishing and commerce. Tidelands unfit for trust purposes, for example, may be put to any useful purpose. ${ }^{216}$ Tidelands may also be relieved of public trust obligations where reclamation to promote trust purposes has rendered the land no longer subject to tidal action. ${ }^{217}$

Activities not closely related to the public trust, authorized by legisla-

212 Illinois Cent. R.R. v. Illinois, 146 U.S. 387,452 (1892). See also LeRoy v. Dunkerly, 54 Cal. 452 (1880); CAI. Crv. CODE $\S 670$ (West 1954). This part does not discuss the extent to which the state's exercise of trust powers may be limited or confirmed by the powers of the federal sovereign. See United States v. Cahifornia, 381 U.S. 139 (1965); United States v. California, 332 U.S. 19 (1947); Submerged Lands Act, 43 U.S.C. $\$ 1301$ (1964); Note, Effect of the Navigation Servitude on Land Reclamation, 2 Corun. J.L. \& Soc. Prob. 75 (1966).

213 That the legislature may authorize $\mathrm{BCDC}$ to protect the public rights in tidelands seems clear from the acknowledged capacity of mumicipalities to administer the trust. See, e.g., Newcomb v. City of Newport Beach, 7 Cal. 2d 393, 60 P.2d 825 (1936).

214 The sales were stopped by the legislature in 1909, CAT. Pus. Res. Cope $\$ 7991$ (West 1956), and from that year on the legislature made at least one grant to a public entity at every regular session. The grantee cities, counties and districts in the San Francisco Bay Area are listed in Staff of Jonnt Legistative Commtrtee on Thoedands, 1 Catirornia's Tidetands Trusts, Exhibit 1 (1965). See generally M. Scott, The Future of Sas Francisco Bay 1-23, 117-25 (1963).

215 R. HaIr, supra note 213 , at 5-6.

216 Boone v. Kingsbury, 206 Cal. 148, 273 P. 797 (dictum), cert. denied, 280 U.S. 517 (1929); Ward v. Mulford, 32 Cal. 365 (1867).

217 The cases nost frequently involve harbor improvements. See Atwood v. Hammond, 4 Cal. 2d 31, 48 P.2d 20 (1935); Eldridge v. Cowell, 4 Cal. 80 (1854); cf. Henry Dalton \& Sons Co. v. City of Oakland, 168 Cal. 463, 467, 143 P. 721, 722 (1914). 
tive grants to public grantees, ${ }^{218}$ have been upheld by the courts as promoting trust purposes. Restaurants and motels have been deemed permissible commercial purposes, ${ }^{219}$ and the construction of an armed services Y.M.C.A. on tidelands has been upheld as a "necessary and convenient" facility for promoting commerce and navigation. ${ }^{220}$ Other uses, not yet judicially reviewed, to which the legislature has authorized cities to put tidelands include airports, ${ }^{221}$ sports facilities, ${ }^{222}$ bathing facilities, ${ }^{223}$ and "recreational, educational, industrial, commercial and residential purposes in which there is a general statewide interest."224

\section{B. BCDC Exercise of the Trust: Public Grantees}

Whether rights acquired from the legislature by public grantees may now be circumscribed by BCDC in fulfilling the state's responsibility to maintain the public trust would appear decided in favor of the Commission. In City of Coronado v. San Diego Unified Port District ${ }^{225}$ the court examined the validity of a statute requiring certain cities to convey their title in tidelands to a harbor district. ${ }^{226}$ The city of Coronado complained that this act was invalid because it conflicted with a 1923 conveyance of the same tidelands from the state to the city, "to be forever held ... in trust" for navigation, fishing and commerce. ${ }^{227}$ The court found "no cogent reason why, in order to enhance the public welfare, the state should not be entitled or legally able to alter or extinguish the interest

218 Oakland was first in the parade of cities to receive such grants, prompted by the increased need for harbor space resulting from the opening of the Panana Canal. Ch. 390, [1909] Cal. Stats. 665; M. ScorT, supra note 214, at 11-12. Land granted to a city by the state may be subleased by the city for public uses consistent with the trust. CAI. Crv. CODE § 718 (West 1954); CAL. Gov'T Code \$§ 37380-95 (West 1955).

219 Martin v. Smith, 184 Cal. App. 2d 571, 7 Cal. Rptr. 725 (1960). But of. Colberg, Inc. v. State, 246 A.C.A. 864, 55 Cal. Rptr. 159 (1966) (freeway), argument heard, Sac. No. 7694, (Cal. Sup. Ct., May 2, 1967).

220 People v. City of Long Beach, 51 Cal. 2d 875, 338 P.2d 177 (1959). This judicial approval of a public grantee putting reclaimed tidelands to uses consistent with the trust might, by analogy, also permit BCDC regulations of privately owned, reclaimed tidelands on the theory that such land is still susceptible of use for "commerce" and therefore subject to state trust regulation. No California case has examined this contention; the courts assume without discussion that private reclaimed land, unlike land held by public grantees, is no longer useful for trust purposes.

221 Ch. 1028, [1955] Cal. Stats. 1936; ch. 483, [1947] Cal. Stats. 1385; ch. 607, [1943] Cal. Stats. 2189.

222 Ch. 15, [1960] Cal. Stats. 1st Ex. Sess. 319.

223 Ch. 681, [1929] Cal. Stats. 1172; ch. 78, [1925] Cal. Stats. 181.

224 Ch. 921, [1959] Cal. Stats. 2952.

225227 Cal. App. 2d 455, 38 Cal. Rptr. 834 (1964), appeal dismissed, 380 U.S. 125 (1965).

226 Ch. 67, [1962] Cal. Stats. 1st Ex. Sess. 362, as amended, ch. 673, [1963] Cal. Stats. 1662.

227 Ch. 49, [1923] Cal. Stats. 85. 
of a political or corporate subdivision in any grant made by the state to it ... in trust for the benefit of the public in general."228 The court therefore upheld the legislative disposition of the tidelands to the port district. $^{229}$ It stated that no valid grant of lands covered by navigable waters could impair the power of a subsequent legislature to regulate enjoyment of the public righit ${ }^{230}$ and concluded that, because the state was both settlor and beneficiary of the tidelands trust, ${ }^{231}$ private trust law principles permitted it to "alter, amend, or revoke the trust in any manner which is not contrary to law or public policy."232 This decision is important for basing Bay regulation on the tidelands trust because it clearly permits the state legislature to alter the use and control of tidelands held by public grantees even though prior grants did not reserve to the state any right of subsequent modification.

\section{BCDC Exercise of the Trust: Private Owners}

The extent of the state's right to exercise trust responsibilities over privately owned tidelands is not entirely clear. The question is one of state law, ${ }^{233}$ and in California the precise question has not yet arisen. The following discussion explores the nature of public and private rights in tidelands and concludes that $\mathrm{BCDC}$, a state-created agency, may restrict use of privately owned tidelands consistently with California's prior judicial treatment of the public tidelands trust.

An understanding of the state's tidelands trust powers requires distinguishing between the interests of title owners and the public in tidelands. ${ }^{234} \mathrm{~A}$ title held in fee is a permanent, unconditioned interest,

228 227 Cal. App. 2d at 472, 38 Cal. Rptr. at 843; cf. City of Long Beach v. Morse, 31 Cal. 2d 254, 188 P.2d 17 (1947).

229 The court found several bases for its conclusion. First, art. IV, § 31 of the California constitution forbids a gift of any public thing of value. Second, the beneficiaries of the public trust are not the inhabitants of the grantee municipality but all the people of the state. Mallon v. City of Long Beach, 44 Cal. 2d 199, 205, 282 P.2d 481, 484-85 (1955) (income from granted tidelands must revert to state when legislatively declared free from trust). Third, art. XV, $\S 2$ of the California constitution requires the legislature to do all things necessary to the execution and administration of the public trust, and this requireinent could not be relaxed by application of private trust principles permitting revocation only when such a power has been expressly reserved.

230227 Cal. App. 2d at 474, 38 Cal. Rptr. at 844; accord, Mallon v. City of Long Beach, 44 Cal. 2d 199, 207, 282 P.2d 481, 486 (1955).

231 See People ex rel State Lands Coinm'n v. City of Long Beach, 200 Cal. App. 2d 609, 615, 19 Cal. Rptr. 585, 589 (1962).

232227 Cal. App. at 475, 38 Cal. Rptr. at 845 .

233 Borax Consolidated, Ltd. v. Los Angeles, 296 U.S. 10, 22 (1935); Port of Seattle v. Oregon \& W.R.R., 255 U.S. 56, 63 (1921); Shively v. Bowlby, 152 U.S. 1, 40 (1894); Hardim v. Jordan, 140 U.S. 371, 382 (1891); Barney v. Keokuk, 94 U.S. 324, 338 (1876). 234 These concurrent interests in the same tidelands are discussed by courts under the labels jus privatum and jus publicum. See, e.g., Mlinois Cent. R.R. v. Illinois, 146 U.S. 387 (1892); People v. California Fish Co., 166 Cal. 576, 138 P. 79 (1913). 
disposable solely by its owner. Such title is based on transactions with previous holders of the same title and may be protected by recognized procedures like recordation. A fee interest in tidelands can be good against both private persons and the state. Public trust rights in tidelands, however, are of a different order. They are not freely disposable, but may be terminated only under certain circumstances. ${ }^{235}$ Moreover, the public rights to tidelands depend, not upon transactions between parties or upon protective acts like recordation, but upon the fitness of the tidelands for navigation, fishing and commerce. The following discussion maintains that in California, title to tidelands is freely and permanently alienable by the state, while the public rights remain as long as the tidelands, though privately owned, are suited for trust purposes.

Cases establishing various private rights in tidelands ${ }^{236}$ do not determine whether such private rights prevent the state from protecting public trust rights against the acts of private tidelands owners. California cases indicate that the state is not thus prevented. The state's trust powers are pervasive, as indicated by strong language in Boone v. Kingsbury. ${ }^{237}$ The court, upholding a legislative grant for oil prospecting on tidelands, declared the state's broad trust powers as follows: "The state may at any time remove structures from the ocean erected by its citizens, even though they have been erected with its license or consent, if it subsequently ... finds that they substantially interfere with navigation or commerce." If the state may remove estabhished structures, a fortiori; the state may, through $\mathrm{BCDC}$, prohibit the construction of new ones.

The classic holding in favor of the state's trust powers is in People $v$. California Fish Company, ${ }^{239}$ where the state successfully sought to quiet title to land suitable for trust purposes which had been sold into private

235 See notes 216-17 supra and accompanying text.

236 California courts liave long held that private rights received from the state may, under appropriate circumstances, be adversely possessed. Southern Pac. Co. v. City of San Francisco, 37 Cal. Rptr. 817 (1964), rev'd in part on other grounds, 62 Cal. 2d 50, 396 P.2d 37, 41 Cal. Rptr. 5 (1964); San Francisco v. Straut, 84 Cal. 124, 24 P. 814 (1890). Other private rights in tidelands lave also been upheld. A private leasehold for trust purposes in tidelands granted by the state may bind the lessor-grantee. City of Oakland v. LaRue Wharf \& Warehouse Co., 179 Cal. 214, 176 P. 361 (1918). A private easement for trust purposes may be established against a private title-holder from the state. Connell v. McGahie, $37 \mathrm{Cal}$. App. 439, 173 P. 1115 (1918). In addition to these riglits in tidelands of one private person over another, two California cases indicate by dicta that private title interests may be established against the state. People v. California Fish Co., $166 \mathrm{Cal}$. 576, 586, 138 P. 79, 89 (1913) ; Richmond Wharf \& Dock Co. v. Blake, 39 Cal. App. 1, 4, 177 P. 508 (1918); accord, Hickey v. Illinois Cent. R.R., 35 IIl. 2d 427, 220 N.E. 2 d 415 (1966).

237206 Cal. 148, 273 P. 797, cert. denied, 280 U.S. 517 (1929).

238 Id. at 192-93, 273 P. at 816. See also Appleby v. City of New York, 271 U.S. 364 (1926); Illinois Cent. R.R. v. Illinois, 146 U.S. 387 (1892).

230166 Cal. 576, 138 P. 79 (1913). 
ownership under statutes making no reference to the existence of the trust. The court voided the private patents ${ }^{240}$ and found for the state on two grounds. First, the Cahifornia constitution, by obligating the legislature to protect the public navigation interest in tidelands, automatically subjected all state grants to public trust limitations. ${ }^{241}$ Second, because the sales were pursuant to statutes making no reference to the public trust, the court refused to assume that the legislature, by this silence, lad intended to destroy "the paramount public easement, whicl it was its duty to protect."242 The court recognized private ownership free of trust restrictions only where "the public authorities, by erecting a seawall, or otherwise improving the premises for navigation, exclude lis land or part thereof from the public use."243

These two quotations present an ambiguity in the court's opinion. On the one hand, the court emphasized the legislature's failure to manifest any intent concerning the protection of the trust, thus inhibiting the court from condoning its removal. On the other hand, the court stressed that private tidelands would be free from the trust only when the physical

240 The court expressly reserved the question whether the state could take private improvements for trust purposes without compensation. $166 \mathrm{Cal}$. at $612,138 \mathrm{P} .2 \mathrm{~d}$ at 94 . A later case, Newcomb v. City of Newport Beach, 7 Cal. 2d 393, 60 P.2d 825 (1936), deciding a similar question, went far toward upholding the regulatory power of $\mathrm{BCDC}$ based on the tidelands trust. The legislature had authorized the city to establish a harbor, ch. 70, [1927] Cal. Stats. 125, and the court held that the city could, without payment of compensation, dredge privately owned lands which, like the tidelands in California Fish, had been sold without reference to the trust. The court stated that the legislative grant "vested in the city the right to administer the public trust . . . and, as an incident thereto, the right to make changes and improvements in the interests of navigation and commerce without the exercise of eminent domain." $7 \mathrm{Cal}$. $2 \mathrm{~d}$ at 402,60 P.2d at 829 . The court apparently did not have to decide whether changes more extensive than dredging were permissible, or whether the trust exercise could prevent affirmative acts by the owner. $C f$. Miramar Co, v. City of Santa Barbara, 23 Cal. 2d 170, 143 P.2d 1 (1943) (no compensation for damage to littoral owner); Natcher v. City of Bowling Green, $264 \mathrm{Ky}, 584,95$ S.W.2d 255 (1936).

241 'No individual, partnership, or corporation, claiming or possessing . . . tidal lands of a harbor, bay, inlet, estuary, or other navigable water in this State, shall be permitted ... to destroy or obstruct the free navigation of such water; and the Legislature shall enact such laws as will give the most liberal construction to this provision . . ." CaL. Const. art. XV, \& 2 (West 1954). This section has been held to provide all purchasers subsequent to its ratification in 1879 with notice of the trust limitation. Forestier v. Johnson, 164 Cal. 24, 127 P. 156 (1912). Notice to purchasers before 1879 has three possible bases: (1) The theory that the tidelands have always been subject to the public trust, regardless of the constitutional provision, United States v. Kansas City Life Ins. Co., 339 U.S. 799 (1950); (2) Congress' express condition on Cahforma's admission to the Umion that "all the navigable waters within the said State shall be common highways," Act of Sept. 9, 1850, ch. 50, \& 3, 9 Stat. 452; Mission Rock Co. v. United States, 109 F. 763, 767-68 (9th Cir. 1901); or (3) the early Cahfornia judicial recogmition of the trust, Eldridge v. Cowell, 4 Cal. 80 (1854).

242166 Cal. at 591, 138 P. at 85; accord, Forestier v. Johnson, 164 Cal. 24, 127 P. 156 (1912).

${ }^{243} 166$ Cal. at 596, 138 P. at 87. 
condition of the land prevented any enjoyment of public trust rights. The court did not make clear whether legislative intent or the physical condition of the land should control in removing private tidelands from the trust. $^{244}$

The next important case to deal with the public trust, Knudson $v$. Kearney, ${ }^{245}$ seemed to resolve this ambiguity in favor of the intent of the legislature. In 1908, the plaintiff Knudson constructed two shacks and settled on tideland leased to the defendant Kearney ${ }^{246}$ by a record holder under an 1870 statute authorizing the sale of certain tidelands. ${ }^{247}$ In 1912 the plaintiff brought a quiet title action, alleging that the conveyance was beyond the state's power and that of the Board of Tide Land Commissioners. ${ }^{248}$ The plaintiff therefore claimed better title by his possession of and improvements upon the land. The trial court found for the defendant and the supreme court affirmed.

In upholding the defendant's title, the supreme court seemed to rely on the legislative intent, stating that the statutes authorizing the sale of this land had been "enacted in aid of navigation and for the purpose of providing for the improvement of San Francisco Bay so as to make it more suitable for navigation." 249 This enactment was held to satisfy the California Fish requirement of conscious legislative protection of the public trust. ${ }^{250}$ The Knudson decision upholding the defendant's title might, therefore, be taken to indicate that the state cannot exercise trust control over portions of the Bay still suitable for trust purposes simply because they were sold pursuant to a statute making some reference to the trust. The following discussion will show the error of such an interpretation.

First, Knudson did not involve any question of the scope of the tideland trust over privately owned land. The plaintiff did not assert his public right to fish on the land. The plaintiff only asserted better title and lost on that issue. Second, no rights of the state were determined because the state was not a party to the suit. ${ }^{251}$ Thus any defects which

244 California Fish was cited in Newcomb v. City of Newport Beach, 7 Cal. 2d 393, 60 P.2d 825 (1936), to uphold exercise of the public trust over private tidelands. The court did not rely on the legislature's omission to provide for the public trust in the sale, but focussed rather on the physical condition of the land. It was deemed navigable because rowboats could pass over it at high tide.

245171 Cal. 250, 152 P. 541 (1915).

246 Transcript on Appeal at 16.

$247 \mathrm{Ch} .388$, [1870] Cal. Stats. 541.

248 Complaint, Knudson v. Kearny, Civil No. 37709 (Super. Ct., Alameda County, Cal. Nov. 6, 1912).

$249171 \mathrm{Cal}$. at 253,152 P. at 542.

250 The trust protection afforded by the statute was quite limited. See note 253 , infra.

201 Newcomb v. City of Newport Beach, 7 Cal. 2d 393, 403, 60 P.2d 825, 830 (1936). 
may have existed between defendant and the state were not adjudicated. ${ }^{252}$ Therefore, no right of the state to control defendant's use of the land in protection of navigation, fishing and commerce could have been in issue.

Third, the decision of the court must be rejected if it means that land may be removed from the public trust simply because it was sold under an authorizing statute making limited provision for navigation and commerce. ${ }^{253}$ Such an interpretation would permit the legislature to sell all tidelands into private ownership and remove them from the trust by including in the authorizing legislation any provision indicating some legislative consideration of the trust. This view would permit avoidance of the judicial requirement that the trust may be removed only from land physically rendered unsuitable for trust purposes as part of a project that furthers navigation, fishing or commerce. ${ }^{254}$ This loophole finds support neither in the cases rehed on in $K m u d s o n^{255}$ nor in subsequent opinions citing Kmudson. ${ }^{256}$

252 See South Shore Land Co. v. Petersen, 230 Cal. App. 2d 628, 631, 41 Cal. Rptr. 277, 279-80 (1964).

253 The statute gave the Board of Tide Land Commissioners authority to establish canals anywhere within the lands offered for sale, "whenever they deem them necessary for the purposes of ... navigation and the wants of commerce ...." Ch. 388, \& 2, [1870] Cal. Stats. 541. Power merely to establish canals would seem inadequate to protect against the many possible hindrances to navigation, fishing and commerce, and it does not appear from the statute that the legislature intended this limited power as the sole protection for trust rights in unreclaimed, privately owned tidelands.

254 See People v. Kerber, 152 Cal. 731, 93 P. 878 (1908); Oakland v. Oakland Water Front Co., 118 Cal. 160, 50 P. 277 (1897); Eldridge v. Cowell, 4 Cal. 80 (1854); cf. Henry Dalton \& Sons Co. v. City of Oakland, 168 Cal. 463, 143 P. 721 (1914).

255 San Francisco v. Straut, 84 Cal. 124, 24 P. 814 (1890) held that whatever right a city held in tidelands could be adversely possessed. Pcople v. Williams, 64 Cal. 498, 2 P. 393 (1884), permitted the state to reassume exercise of the trust where a municipal grantee had not fulfilled the terms of the grant. Knight v. Roche, 56 Cal. 15 (1880), held that the State Board of Tideland Conmissioners had no power to convey title to land above the ordinary high-water mark. Hyman v. Read, 13 Cal. 444 (1859) simply construed two legislative acts to determine which had disposed of certain tidelands. Eldridge v. Cowell, 4 Cal. 80 (1854), held merely that land reclaimed in the construction of a harbor may be removed from the trust.

258 Most of the cases cite Knudson for the familiar proposition that land reclaimed in furtherance of trust purposes is susceptible of valid private interests and nontrust uses. Atwood v. Hammond, 4 Cal. 2d 31, 48 P.2d 20 (1935); City of Oakland v. LaRue Wharf \& Warehouse Co., 179 Cal. 208, 176 P. 361 (1918); Koyer v. Miner, 172 Cal. 448, 156 P. 1022 (1916); City of Newport Beach v. Fager, 39 Cal. App. 2d 29, 102 P.2d 438 (1940). In Connell v. McGahie, 37 Cal. App. 439, 173 P. 1115 (1918), the court cited Knudson for the simple declaration that the use of tidelands by the public could be curtailed. The court in People v. Southern Pac. Co., 177 Cal. 555, 171 P. 294 (1918), lacked sufficient evidence to decide the issues raised in Knudson. In Richmond Wharf \& Dock Co. v. Blake, 39 Cal. App. 4, 177 P. 508 (1918), the court stated that a private right may be established against the state in any land not required for navigation. This statement, however, offers no support for a broad interpretation of Knıdson. First, only private title rights, not public trust rights, were at issue. Second, the court acknowledged that the assertion of immunity from state infringement was dictum. 
The accepted California test for removal of privately owned tidelands from the trust is not the intent of the legislature in making the sale or the language of the authorizing statute, but the physical condition of the tideland at the time of the trust exercise. In People v. Kerber, ${ }^{257}$ for example, the supreme court upheld state power over certain tidelands despite the estabhshment of a seawall line. The court reasoned that "for all practical purposes [San Diego] bay is open to navigation to the actual shorehine of higl tide over the land in question as fully and freely as before the line was so located." 258 So long as the tideland is still suitable for trust purposes, it remains subject to the limitations of the trust. ${ }^{250}$ Any test for removal of the trust other than the physical condition of the tideland would permit wholesale evasion by the state of its responsibilities as tidelands trustee.

Therefore, mere sale pursuant to an act including some trust purposes cannot remove privately owned land from the tidelands trust. Though a contrary conclusion might be indicated by certain language in Knudson $v$. Kearney, it is not warranted by the facts of that case and is inconsistent with cases stressing the physical condition of the land. Moreover, a court reviewing BCDC's supervision of the public trust will take into account changes in the region and the Bay that required the Commission's creation and changes in administration of the trust. ${ }^{260}$ The court will defer to an unambiguous legislative declaration that vesting regulatory power in the Commission is the most effective method of protecting public rights in navigation, fishing and commerce. ${ }^{261}$ The legislative decision to give a regional agency public trust authority over privately owned Bay tidelands should be upheld. ${ }^{262}$

257152 Cal. 731, 93 P. 878 (1908).

258152 Cal. at 737, 93 P. at 880; accord, Atwood v. Hammond, 4 Cal. 2d 42, 48 P.2d 20 (1935) (dictum); People v. Williams, 64 Cal. 498, 2 P. 393 (1884).

250 See Newcomb v. City of Newport Beach, 7 Cal. 2d 393, 60 P.2d 825 (1936); cf. Bohn v. Albertson, 107 Cal. App. 2d. 738, 238 P.2d 128 (1951) (navigation and fishing rights apply to land overfiowed by river).

280 "The powers of the state as trustee are not expressed. They are commensurate with the duties of the trust. Every trustee has the implied power to do everything necessary to the execution and administration of the trust." People v. California Fish Co., $166 \mathrm{CaI}$. 576, 597, 138 P. 79, 87 (1913).

261 See Boone v. Kingsbury, 206 Cal. 148, 183, 273 P. 797, 813, cert. denied, 280 U.S. 517 (1929); People v. California Fish Co., 166 Cal. 576, 138 P. 79 (1913).

262 In empowering $B C D C$ with trust responsibilities, the legislature would be acknowledging the shortcomings of prior piécemeal sales and grants, inimical to prudent trust administration. "[T] $]$ he relationship of an individual grant . . to the long-range needs and requirements of the 'State and the region received only minimal consideration in arriving at a judgment as to the conditions which the grant ... should include or in determining if the grant ... should even be inade." Jonit Lerscatrive Comar. on TroeLANDS, 1 CALIFORNIA's Tiderand TRỨsts $24^{\circ}$ (1965). Móre thoughtful ánd effective determination of which Baỳ projects are in the interests of navigation, fishing and commerce can be achieved by a regional agency devoted to that endeavor than by a legislature occupied 


\section{Summary}

Whatever support the police power may provide for the regulation of Bay development, an independent and sufficient basis for such regulation is the trust responsibility of the state to protect public interest in navigation, fishing and commerce in tidal waters. Sucl an exercise of the trust power through a regional agency would be consistent with the rights of private owners and public grantees. The state's broad trust powers appear adequate to empower a legislatively created regional agency to adopt and enforce a rational plan for the development of San Francisco Bay, a plan one of whose major purposes would be the protection and promotion of navigation, fishing and commerce.

\section{CONCLUSION}

The success of man's efforts to master his environment has always depended on his knowledge, patience, and willingness to cooperate. For San Francisco Bay, where commercial pressures and natural resource values must both be accommodated, these qualities liave recently coalesced in a temporary but effective regional agency, the San Francisco Bay Conservation and Development Commission. The Commission discharges the intricate and essential task of resolving conflicting demands on the Bay. The analysis in this Comment shows that certain legal obstacles do not hinder the Commission in this task. The contribution of Bay regulations to the region's general welfare permits their enforcement through the police power. Because such regulations protect navigation, fishing and commerce, the Commission may enforce them as the designated protector of the public' trust rights in tidelands. State constitutional home

with the needs of the entire state or a municipality unwilling to forsake its own interests.

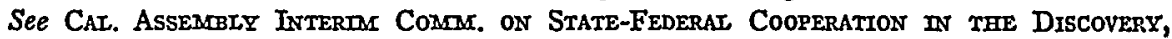
Transportation, Refining, and Use of Petroleum Oil and its Products Final Rep, in 4 Journat of THe Assemsaly 6143 (Reg. Sess. 1951).

There is precedent in California for judicial consideration of these shortcomings in the legislative disposition of tidelands. In Oakland v. Oakland Water Front Co., 118 Cal. 160, 174,50 P. 277, 282 (1897), Chief Justice Beatty noted "the well-known fact that the legislature has but little time to deliberate upon mass of bills brought before it, and that it is very often imposed upon, and oftener still mistaken, as to matters vitally connected with the subjects of litigation." Beatty pointed out that the legislature itself had acknowledged this problem by enacting CAI. Crv. CODE $\S 1069$ (West 1954), requiring grants by public bodies or officers to be construed in favor of the grantor. It would therefore be a departure from this realistic posture for a court to restrict the tidelands trust authority of the BCDC, whose creation was an effort to promote the rational development of San Francisco Bay free from the lazards, noted by Chief Justice Beatty, of direct legislative responsibility. The persistence of these hazards, aggravated by increasing pressures on the Bay, is evidenced by the attempts of some legislators to override BCDC application denials. See S.B. 1064,.Cal. 1967 Sess., designed to remove a proposed 160-acre garbage dump in the Bay from BCDC jurisdiction; San Francisco Chronicle, June 22, 1967, at 1, col. 6. 
rule provisions do not invalidate such regionally enforced regulations because the problems of the Bay extend beyond municipal boundaries and cannot be adequately controlled by local governments. A legal basis thus exists for the rational protection and development of San Francisco Bay. The responsibility rests with the state legislature to take advantage of the opportunity thus presented. Increasing pressures on the Bay require that the legislature use its power to give the Commission a permanent form, so that the Bay may be preserved as the outstanding natural asset in the San Francisco region.

Daniel U. Smith 